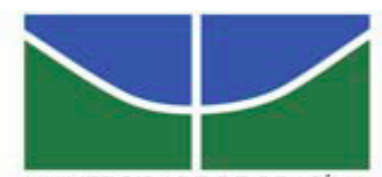

UNIVERSIDADE DE BRASÍLIA

Centro de Excelência em Turismo

Pós-graduação Lato Sensu

Curso de Especialização em Gestão de Negócios em Turismo

\title{
A IMAGEM TURÍSTICA DE BRASÍLIA NA VISÃO DO VISITANTE: UM ESTUDO SOBRE POSICIONAMENTO NUMA ÓTICA DE MARKETING
}

Thadeu Costa Andrade

Josivânia Silva Farias

MSc.

Brasília - 2007 


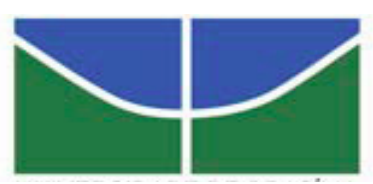

UNIVERSIDADE DE BRASÍLIA

Centro de Excelência em Turismo

Pós-graduação Lato Sensu

Curso de Especialização em Gestão de Negócios em Turismo

\title{
A IMAGEM TURÍSTICA DE BRASÍLIA NA VISÃO DO VISITANTE: UM ESTUDO SOBRE POSICIONAMENTO NUMA ÓTICA DE MARKETING
}

\author{
Thadeu Costa Andrade \\ Josivânia Silva Farias \\ MSc.
}

\begin{abstract}
Monografia apresentada ao Centro de Excelência em turismo - CET, da Universidade de Brasília - UnB, como requisito parcial à obtenção do grau de Especialista em Gestão de Negócios em Turismo.
\end{abstract}


Andrade, Thadeu Costa.

A Imagem Turística de Brasília na Visão do Visitante: Um Estudo Sobre Posicionamento Numa Ótica de Marketing/ Thadeu Costa Andrade. - Brasília, 2007.

$\mathrm{xi}, 55$ fij.

Monografia (Gestão de Negócios em Turismo) Universidade de Brasília, Centro de Excelência em Turismo, 2007.

Orientador (a): Josivânia Silva Farias.

1. Imagem. 2. Brasília. 3. Visão. 4. Visitante. I. Título.A Imagem Turística de Brasília na Visão do Visitante. II. Título: Estudo Sobre Posicionamento Numa Ótica de Marketing. 


\section{UNIVERSIDADE DE BRASÍLIA}

Centro de Excelência em Turismo

Pós-graduação Lato sensu

Curso de Especialização em Gestão de Negócios em Turismo

Thadeu Costa Andrade

Aprovado por:

\begin{tabular}{c}
\hline MSc. Josivânia Silva Farias \\
\hline MSc. Domingos Sávio Spezia \\
\hline
\end{tabular}

MSc. Shirley Pontes

Monografia apresentada ao Centro de Excelência em turismo - CET, da Universidade de Brasília - UnB, como requisito parcial à obtenção do grau de Especialista em Gestão de Negócios em Turismo.

Brasília, de de 20 
DEDICATÓRIA

Essa monografia é dedicada à mulher, mola propulsora da minha vida e meu forte. Pessoa que é exemplo de companheirismo, força, coragem, amiga, mulher e mãe. Esse trabalho é para Senhora mainha. Mulher da minha vida... Te amo!!! 


\section{AGRADECIMENTOS}

Agradeço a essa energia maior que nos envolve a qual chamo de Deus.

Aos meus pais, Neide e Luiz, por todo amor, dedicação, ajuda, carinho, respeito e apoio que mesmo à distância continuam me dedicando.

Aos meus irmãos, Emília e Marcelo. Em especial à minha irmã Emília, exemplo de mulher e de amiga.

Aos meus avós Bequinho e Maria (in memorian).

A Tia Nélia, por toda ajuda, compreensão e carinho dispensado a mim.

A minha madrinha Jilda, meu "madrinho" Ruy e meu irmão Saulo, por tudo que fizeram e fazem por mim. Amo vocês!!!

A família De Paula, pelo acolhimento e ajuda. Em especial a Afonso pela receptividade e amizade.

A minha grande, amada, querida, companheira, amiga Sheila, pela dedicação, ajuda, carinho, amor, cumplicidade, compreensão e companheirismo dedicado a mim por todos esses anos de convivência. Obrigado por fazer parte da minha vida.... Te amo muito MÃE!!!!

Aos meus queridos amigos irmãos Cláudia e Jack, que mesmo a distância preocupamse comigo e dedicam-me atenção, amor, carinho e ajuda.

Aos amigos Rodrigo, Kellen, Flávia, Cris e Wal, por toda dedicação, carinho e ajuda durante essa jornada, e à turma da especialização, pela tolerância e animação.

Ao pessoal da SERVESYN e SYNLOGíSTICA, por todo apoio e compreensão. Em especial aos amigos Beto, Janine, Marilene e Mileide. 
A professora, orientadora e amiga Josivânia Farias, por toda ajuda, compreensão, apoio, dedicação e carinho dispensados.

Aos professores e funcionários do CET. Em especial a Luis, por toda ajuda e paciência com a turma. 


\section{RESUMO}

Brasília, cidade com 46 anos, oferta vários segmentos turísticos como: Turismo Cívico, Turismo Religioso, Turismo de Lazer, Turismo de Negócios, Turismo de Eventos, Convenções, dentre outros. Assim o turismo desponta em Brasília com uma força multiplicadora de empregos e geradora de divisas e renda interna. Com isso, a finalidade desse trabalho foi identificar o nível de percepção dos visitantes sobre a imagem turística de Brasília, abordando os principais motivos que os trazem a cidade, e dessa forma, averiguar quais os segmentos em potencial da capital. Para alcançar os objetivos propostos desta pesquisa científica, foi utilizado o método descritivo quantitativo, pois este está associado à experimentação e manipulação de um objeto estudado em uma população ou universo. Nesse caso, o universo foi de 315 (trezentos e quinze) visitantes, sendo que o instrumento de coletas de dados da pesquisa foi o questionário. Os resultados alcançados mostram que desde 2005 o motivo primordial que atrai turistas são "negócios", aparecendo em segundo lugar o motivo "lazer". Mesmo com essas informações, percebe-se que a cidade não desvinculou-se, para os visitantes, de sua imagem política. Em suma, nota-se que é preciso um maior empenho dos órgãos públicos e privados em marketing para construir uma imagem turística para Brasília, visto que imagem é um constructor do comportamento do consumidor que indica sua atitude pré-compra. Contudo, constatou-se que a cidade possui grande potencial para a atividade turística, visto que, no último estudo realizado pela Secretaria de Turismo do DF sobre o Turismo Receptivo no Distrito Federal de 2005, a cidade recebeu 936.115 (novecentos e trinta e três mil, cento quinze) visitantes, comprovando assim a grande procura pelo destino Brasília.

PALAVRAS-CHAVE: turismo, posicionamento, imagem turística, marketing 


\begin{abstract}
Brasilia, a 46 year old city, offers many tourist segments such as: Civil Tourism, Religious Tourism, Leisure Tourism, Business Tourism, Conferences and Conventions Tourism, among others. As a result, tourism has been growing in Brasilia with a multiplying force of employment, generating divides and internal income. The aim of this dissertation is to identify the visitor's level of perception of Brasilia's tourist image, touching on the main reasons that bring them to the city and in this way, verify which the potential segments in the Capital City are. In order to achieve the goals proposed by this scientific research, a quantitative descriptive method was used, as it is associated to experimenting and handling an object studied in a population or universe. In this case, the universe was of 315 (three hundred and fifteen) visitors, using questionnaire as the instrument of data collection for the survey. The results obtained show that since 2005, the main reason that attracts tourists to Brasilia is "business", "leisure" is in second place. Even with this information it can be noted that the city has not lost its political image to the visitors. It is also noticed that there is a need for greater effort from public and private marketing bodies to build a tourist image of Brasilia, after all, image is what builds the consumer's behaviour, indicating his or hers pre-purchase attitude. However, it was established that the city has great potential for tourist activity, as seen in the last study carried out by the Federal District's Tourism Bureau about Receptive Tourism in the Federal District in 2005. The study showed that Brasilia received 936.115 (nine hundred and thirty six thousand and one hundred and fifteen) visitors, proving that there is great demand for the destination Brasilia.
\end{abstract}

KEY WORDS: tourism, positioning, tourist image, marketing 


\section{LISTA DE ILUSTRAÇÕES}

Ilustração I: Quadro 1 - Segmentação Psicográfica..................................................11

Ilustração II: Quadro 2 - Segmentação comportamental...........................................12

Ilustração III: Quadro 3 - Segmentação demográfica pessoal...................................13

Ilustração IV: Quadro 4 - Segmentação demográfica socioeconômica.........................13

Ilustração V: Quadro 5 - Segmentação geográfica socioeconômica.............................14

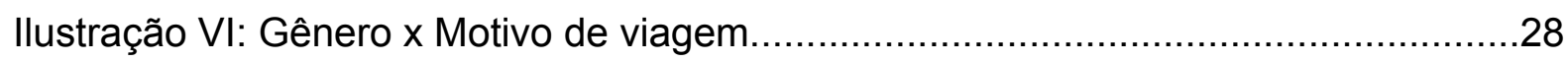

Ilustração VII: Gênero x Quantas vezes o (a) Senhor (a) esteve na cidade..................28

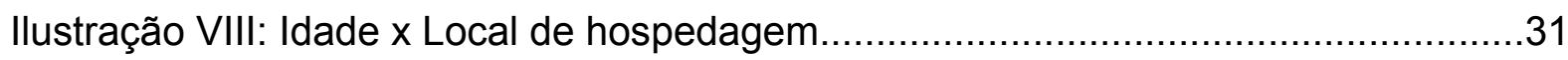

llustração IX: Região de origem dos visitantes x Motivo de viagem..............................32

Ilustração X: Ocupação x A que o (a) Senhor (a) relaciona Brasília -

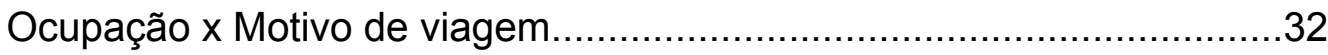

Ilustração XI: Renda x Comparação com outras cidades............................................33

Ilustração XII: Renda x O que o (a) traria novamente a cidade.....................................34

Ilustração XIII: Educação x O (a) Senhor (a) voltaria a Brasília......................................35

Ilustração XIV: Educação x Percepção do turismo em Brasília.......................................36

Ilustração XV: Cruzamento: Grau de Escolaridade x Comparando a outras

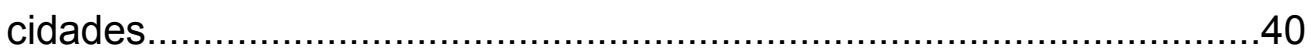

Ilustração XVI: Cruzamento: Ocupação x Comparando a outras cidades.....................40

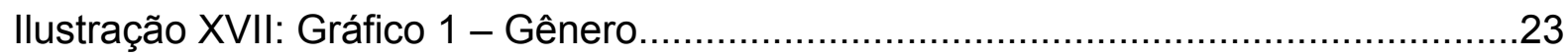

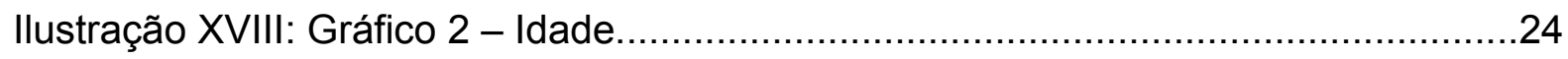

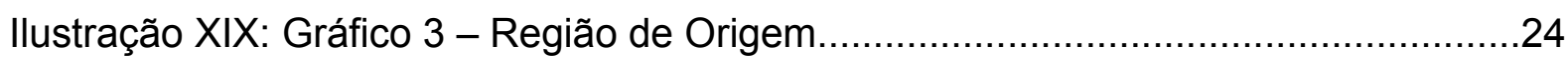

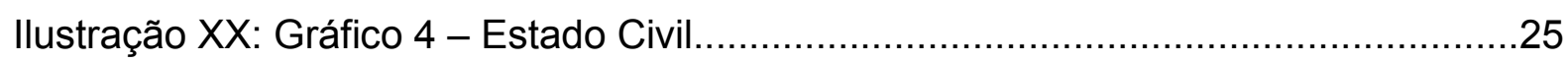

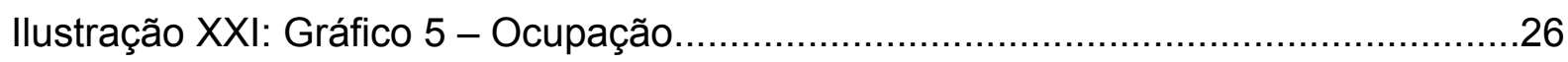

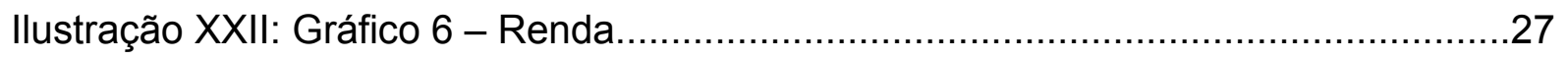

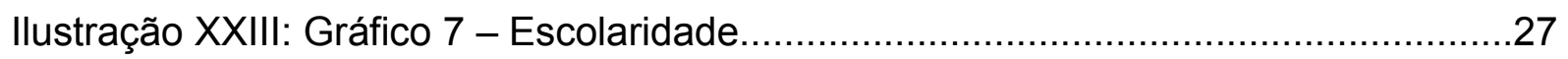

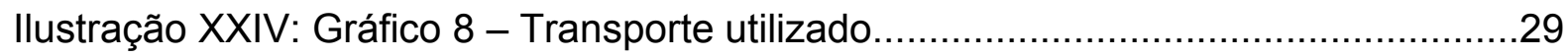

llustração XXV: Gráfico 9 - O (a) Senhor (a) voltaria a Brasília....................................30

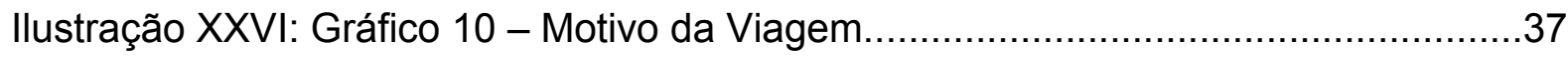


Ilustração XXVII: Gráfico 11 - Freqüência do motivo que o traria novamente a cidade... 38

Ilustração XXVIII: Gráfico 12 - Expectativas dos visitantes em relação aos produtos e serviços turísticos que Brasília oferece. 39

Ilustração XXIX: Gráfico 13 - Visão do turismo em Brasília. .42

Ilustração XXX: Gráfico 14 - Percepção dos visitantes sobre a cidade de

Brasília. 


\title{
LISTA DE ABREVIATURAS E SIGLAS
}

\author{
CNTUR: Conselho Nacional de Turismo \\ DF: Distrito Federal \\ EMBRATUR: Empresa Brasileira de Turismo \\ FUNGETUR: Fundo Geral de Turismo \\ OMT: Organização Mundial de Turismo \\ PIB: Produto Interno Bruto
}

SPSS: Statistical Package for Social Sciences 


\section{SUMÁRIO}

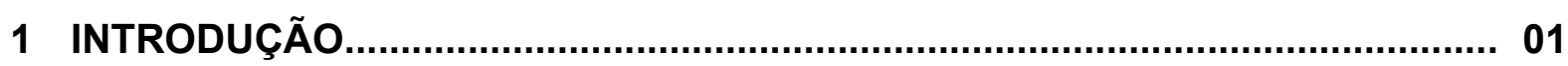

1.1 Problemática

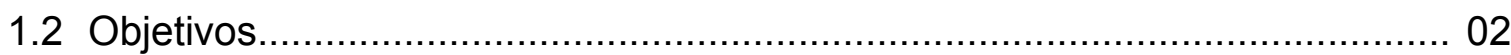

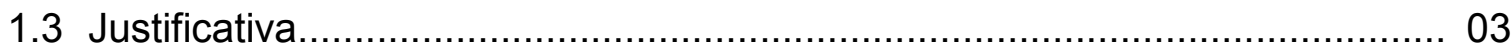

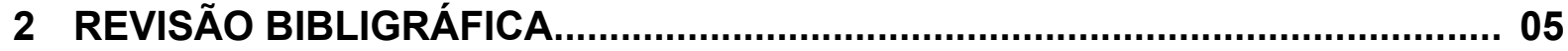

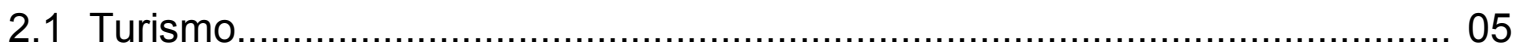

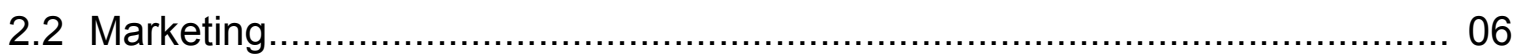

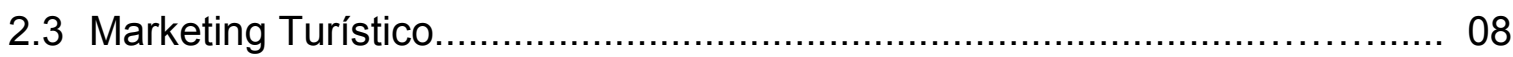

2.4 Segmentação de Mercado..................................................................... 09

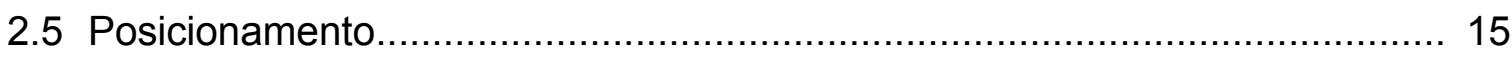

3 METODOLOGIA

3.1 Instrumento e Coleta de Dados................................................................ 20

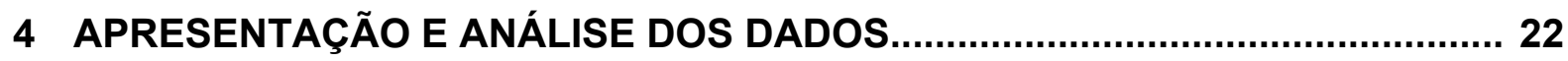

4.1 Análise Descritiva ............................................................................. 23

4.1.2 Características Socioeconômicas................................................... 26

4.1.3 Cruzamentos significativos....................................................... 28

4.2 Potenciais segmentos que podem ser alvo de esforços mercadológicos....... 36

4.3 Principais motivos que trazem as pessoas a Brasília.................................... 37

4.4 Expectativas dos visitantes em relação aos produtos e serviços turísticos que a cidade oferece................................................................... 39

4.5 A percepção dos visitantes sobre a imagem turística de Brasília................... 41

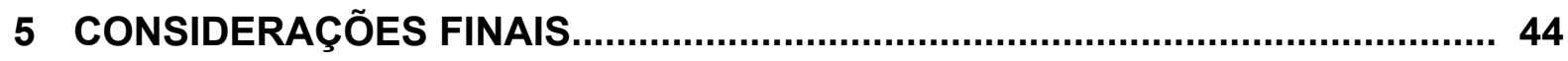

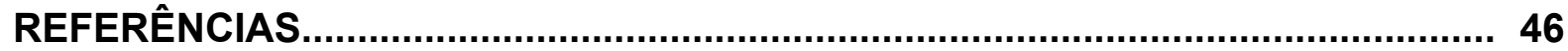

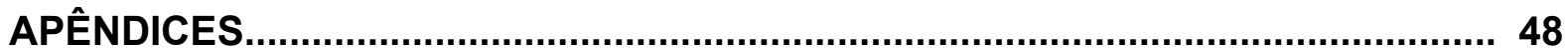

APÊNDICE A - Questionário Aplicado aos Turistas em Brasília.............................. 49

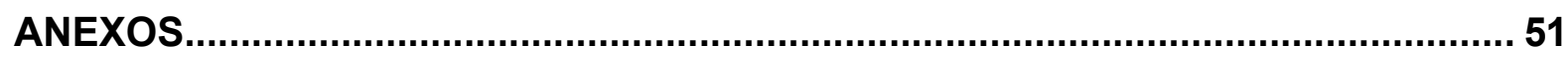

ANEXO A - Dados sobre turismo receptivo no Distrito Federal........................... 52 


\section{INTRODUÇÃO}

Brasília, Capital do Brasil, cidade com 46 (quarenta e seis) anos, recebeu em 2004 novecentos e trinta e seis mil, cento e quinze visitantes, segundo o estudo de Turismo receptivo no Distrito Federal de 2005 (ver Anexo A). O estudo ainda mostra que o PIB do turismo no DF em 2004 foi de $\mathrm{R} \$ 3.046 .479,29$ (envolvendo apenas gastronomia, hotelaria e transporte). Compreendendo $7,2 \%$ na economia do DF, tornando Brasília o $5^{\circ}$ maior destino turístico do Brasil.

Segundo o estudo realizado como mostra o Anexo A, o principal motivo da vinda destes visitantes à capital federal, deve-se, principalmente, à realização de negócios ou à participação em eventos.

Para o Brasília e Região Convention \& Visitors Bureau - BS\&VB, a cidade é bastante requisitada para a realização de eventos profissionais e encontros políticos. Transformando-se em um palco ideal para quem precisa dar repercussão às suas idéias e propostas.

Também é sabido o quanto às empresas privadas e os órgãos públicos ligados direta ou indiretamente à atividade turística vêm investindo em melhorias nos produtos/serviços turísticos, divulgando intensivamente o destino Brasília em todo Brasil e também no exterior. Brasília possui inúmeras possibilidades de crescimento na atividade, pois o turismo vem despontando no Distrito Federal como uma força multiplicadora de empregos e geradora de divisas e renda interna.

Baseada nessas informações e buscando definir uma imagem turística de Brasília, a presente pesquisa pretendeu estudar 'a imagem turística de Brasília 
na visão do visitante: um estudo sobre posicionamento numa ótica de marketing'.

\subsection{Problemática}

Definir uma imagem turística de Brasília e segmentar a atividade já não é mais uma novidade, muito pelo contrario, é questão de gestão de informação e também de adaptação à atividade (dinâmica) do turismo.

Entretanto, pesquisar sobre o turismo na ótica dos visitantes/clientes torna-se conveniente, pois identifica a opinião dos mesmos sobre o setor e também sobre a cidade e seus produtos/serviços, além de identificar possíveis necessidades dos mesmos.

Sendo assim, busca-se analisar como o visitante de Brasília posiciona esse destino em coerência entre o que ele percebe e com os esforços de marketing realizados pela Secretaria de Turismo do DF?

\subsection{Objetivos}

O objetivo geral deste estudo é identificar o nível de percepção dos visitantes sobre a imagem turística de Brasília, considerando a abordagem mercadológica do "posicionamento" de produtos turísticos.

Os objetivos específicos para alcançar o objetivo geral do estudo são: 
- Identificar o perfil demográfico, econômico, social e comportamental dos turistas entrevistados;

- Verificar, através do perfil dos turistas, quais segmentos podem ser melhor aproveitados;

- Enumerar os principais motivos que levam as pessoas a Brasília;

- Caracterizar as expectativas dos visitantes em relação aos produtos e serviços turísticos que a cidade oferece; e

- Levantar como os turistas "posicionam" Brasília, ao relatarem, a partir de suas percepções, a imagem turística de Brasília.

\subsection{Justificativa}

O trabalho justifica-se por ser uma forma de mensuração dos esforços em marketing dos órgãos públicos e privados para posicionar Brasília, além de perceber a satisfação dos clientes/turistas em relação às suas expectativas e também um meio de identificar as necessidades em relação a outros serviços turísticos ainda não aproveitados e de sua opinião sobre o destino Brasília.

Com a obtenção dos dados da pesquisa, foi possível fazer uma reflexão sobre os caminhos e vertentes que a atividade turística vem tomando nas áreas promocionais e empreendedoras em Brasília.

A metodologia utilizada neste estudo foi a pesquisa descritiva quantitativa com uma amostra de 315 visitantes, utilizando como instrumento de coleta de dados 
o questionário (ver apêndice A) e o plano de tratamento de dados foi a tabulação no SPSS - Package for Social Sciences.

O trabalho foi estruturado em 5 capítulos: sendo este introdutório; o segundo a Revisão Bibliográfica, onde elencou-se conceitos significativos; o terceiro compreende a Metodologia, onde explicou-se as técnicas e ferramentas para a construção da pesquisa; o quarto referiu-se à Apresentação a Análise dos Resultados, no qual foi esmiuçado as dados adquiridos através da tabulação dos questionários; e o quinto capítulo Considerações Finais, buscou-se de forma concisa e coerente responder os objetivos propostos pela pesquisa. 


\section{REVISÃo BIBLIOGRÁFICA}

Nesse capítulo serão apresentados temas diretamente ligados à pesquisa (turismo, marketing, marketing turístico, segmentação de mercado e posicionamento), onde mesclou-se visões conceituais, de vários autores, que buscam definir e mostrar a importância dos temas elencados.

\subsection{Turismo}

Para Ignarra (1999), o turismo iniciou quando o homem deixou de ser sedentário e passou a viajar motivado pelo comércio com outros povos. Portanto, é aceitável admitir que o turismo de negócios antecedeu o de lazer; assim como o turismo de aventura, de saúde, religioso é datado de milhares de anos antes de Cristo.

Segundo McIntosh (1993), apud Ignarra, (1999, p.15) o turismo deve ter surgido com os babilônicos por volta de 4000 a.C.:

A invenção do dinheiro pelos sumerios (babilônios) e o auge do comércio que se iniciou aproximadamente no ano 4000 a. C., tal época sinala o início da era moderna das viagens. Os sumerios foram os primeiros a conceber a idéia do dinheiro, e a aplicá-la em suas transações comerciais.

No Brasil, para Ignarra (1999), a história do turismo começou com o seu próprio descobrimento. Sendo que só em 1968 o governo criou os primeiros instrumentos de regulamentação da atividade com a criação do CNTUR - Conselho Nacional de Turismo, o FUNGETUR - Fundo Geral de Turismo e a EMBRATUR - Empresa Brasileira de Turismo.

A Organização Mundial de Turismo - OMT na Cartilha de Segmentação do Turismo (2006, p. 4) conceitua turismo como "as atividades que as pessoas realizam durante viagens e estadas em lugares diferentes do seu entorno habitual, por um período inferior a um ano, com finalidade de lazer, negócios ou outras". 
Para Goeldner, 1992 apud Trigueiro, (2001, p.14), turismo pode ser definido "como o somatório dos fenômenos e relações que surgem da interação dos turistas, empresas, governos e comunidades receptoras no processo de atração e recepção destes turistas e outros viajantes".

\subsection{Marketing}

Para Middleton (2002), seria conveniente se houvesse apenas uma definição de marketing. Entretanto, existem dezenas de definições que são variações individuais "dentro de um amplo consenso de que o conceito de marketing é orientado a lucros e a clientes". (MIDDLETON, 2002, p.24).

Kotler (2000) crê que dentre todas as definições de marketing, pode-se estabelecer uma distinção entre as definições gerenciais e sociais. Assim, uma definição social do marketing mostra o papel desempenhado pelo marketing na sociedade; já a definição gerencial, o marketing é freqüentemente descrito como vender produtos.

Para Kotler (2000, p.30), socialmente falando, "marketing é um processo social por meio do qual pessoas e grupos de pessoas obtêm aquilo de que necessitam e o que desejam com a criação, oferta e livre negociação de produtos e serviços de valor com outros".

Entretanto, a American Marketing Association, 1995 apud Kotler (2000, p.30), oferece a seguinte definição gerencial de marketing:

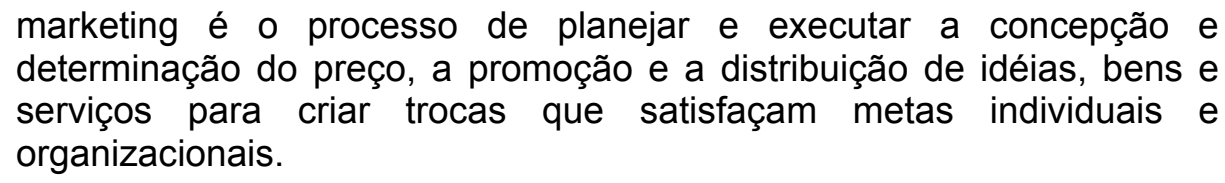
determinação do preço, a promoção e a distribuição de idéias, bens e serviços para criar trocas que satisfaçam metas individuais $\mathrm{e}$ organizacionais.

Segundo Trigueiro (2001, p.10) "fazer marketing significa usar a ciência e a arte para facilitar o processo de troca, isto é, o marketing é o mecanismo de articulação entre a procura e a oferta". 
Essa última definição compreende as duas vertentes do conceito de marketing que Kotler (2000) defende. Entretanto, Trigueiro (2001) mescla os viés sintetizando em uma definição à importância da satisfação mútua entre clientes e organização. Para Trigueiro (2001, p.11):

o marketing, como função empresarial, tem por objetivo criar e manter um forte vínculo entre a organização e seu mercado, a fim de delinear oportunidades e precaver-se de ameaças, o que resulta em produtos ou serviços com as características adequadas àquele mercado.

O objetivo do marketing para Zardo (2003, p.79), "é tornar a venda supérflua. É conhecer e compreender o cliente muito bem, de modo que o produto ou serviço se ajuste a esse cliente e a venda aconteça por si própria". Segundo Zardo (2003, p.88):

o desafio das pessoas que trabalham com marketing consiste em entender o consumidor, no sentido de atender suas expectativas, antes, durante e após a compra, identificando tanto suas necessidades e desejo como também as satisfações ou insatisfações contraídas pelo consumo dos produtos ou dos serviços vendidos.

Assim, Zardo (2003, p. 79) define marketing como o "processo social e gerencial por meio do qual indivíduos e grupos obtêm aquilo de que necessitam e desejam pela criação e troca de produtos e valores".

Para Hooley, et al. (2001, p. 6):

Basicamente, o conceito de marketing diz que, em mercados cada vez mais competitivos e dinâmicos, as empresas ou organizações mais prováveis a vencer são aquelas sensíveis às expectativas, desejos e necessidades e que se engrenam para satisfazer mais seus clientes do que o fariam seus competidores. Isso prova que não há razão para os consumidores comprarem os produtos ou serviços de uma empresa, a não ser que essa empresa esteja de algum modo oferecendo de uma forma melhor de atender a seus desejos e necessidades do que aquelas formas disponíveis por outras empresas concorrentes.

Dessa forma, Zardo (2003, p. 98) conceitua e atribui ao marketing grande importância, pois "(...) para se alcançar os objetivos organizacionais, é necessário determinar as 
necessidades e os desejos dos mercados-alvo e proporcionar as satisfações desejadas de maneira mais efetiva e eficientes que seus concorrentes".

\title{
2.3 Marketing turístico
}

Para Middleton (2002, p. 25), "os leitores devem saber que o marketing em turismo não é uma disciplina distinta, mas uma adaptação dos princípios básicos que foram desenvolvidos e praticados durante várias décadas em uma vasta gama de produtos para consumidores".

Trigueiro (2001) define que o marketing no turismo desempenha um papel fundamental de articulador entre a oferta e a procura. Sendo a sua função, identificar os segmentos de mercado, desenvolver e promover os produtos turísticos e apresentar informações relevantes sobre os produtos/serviços oferecidos.

Segundo Vaz (2001), para enquadrar-se na perspectiva operacional, adota-se o conceito de marketing turístico baseado em definição genérica formulada por Philip Kotler, na qual diz: "Marketing Turístico é o conjunto de atividades que facilitam a relação de trocas entre os diversos agentes que atuam, direta ou indiretamente, no mercado de produtos turísticos". (2001, p.18).

Para Rose (2002), a maioria dos autores, ao definirem marketing turístico, adotam a ótica do produtor, buscando adquirir resultados em troca da satisfação de necessidades e desejos que seus produtos e/ou serviços oferecem aos consumidores. Sendo assim, o marketing turístico para Krippendorf, 1971 apud Rose, (2002, p.20), é definido como:

\begin{abstract}
A adaptação sistêmica e coordenada da política das empresas de turismo, assim como da política turística privada e do estado, sobre o plano local, regional, nacional e internacional, visando a plena satisfação das necessidades de grupos determinados de consumidores, obtendose com isso um lucro apropriado.
\end{abstract}

Goeldner, et al. (2002, p. 403) defende que:

As organizações turísticas que praticam o conceito de marketing descobrem que o consumidor quer, para depois produzirem aquilo que 
satisfará seus desejos, com lucro. O conceito de marketing requer que o pensamento gerencial seja direcionado para os lucros, em vez de para o volume de vendas.

\subsection{Segmentação de mercado}

Para Goeldner, et al. (2002), segmentar é uma estratégia de marketing que determina exatamente quais serão os mercados-alvo que se pretende atingir. Complementando, para Richers, (In PIMENTA, RICHERS, 1991, p.13) “a segmentação é uma forma específica de estratégia de marketing, que precisa ser bem entendida e programada para ser eficaz".

Segundo Ansarah (2000, p. 9), "segmentar o mercado é identificar clientes com comportamentos homogêneos quanto a seus gostos e preferências".

A segmentação de mercado para Chisnall (1985), apud Middleton (2002, p. 113):

(...) reconhece que as pessoas são diferentes quanto aos gostos, necessidades, atitudes, estilos de vida, tamanho e composição da família etc... É uma política deliberada de maximizar a demanda do mercado direcionando os esforços de marketing para subgrupos significativos de clientes ou consumidores.

Assim, resumindo e agrupando conceitos, Middleton (2002, p. 117) prega que:

A segmentação pode (...) ser definida como o processo de divisão de um mercado total - como todos os visitantes - ou um setor do mercado como viagens de férias - em subgrupos ou segmentos para fins de gerenciamento de marketing. Sua finalidade é facilitar o marketing eficaz em termos de custos através da formulação, promoção e entrega de produtos destinados a um fim que atendam às necessidades identificadas de grupos-alvo. Em outras palavras, a segmentação é justificada com o pretexto de atingir maior eficiência na oferta de produtos que atendem à demanda identificada e maior eficácia em termos de custos no processo de marketing. 
Para Beni (2001, p. 153):

A melhor maneira de estudar o mercado turístico é por meio de sua segmentação, que é a técnica estatística que permite decompor a população em grupos homogêneos, e também a política de marketing que divide o mercado em partes homogêneas (...). Essa segmentação possibilita o conhecimento dos principais destinos geográficos e tipos de transporte, da composição demográfica dos turistas, como faixa etária e ciclo de vida, nível econômico ou de renda, incluindo a elasticidadepreço da oferta e da demanda, e da sua situação social, como escolaridade, ocupação, estado civil e estilo de vida.

Na Cartilha de Segmentação do Turismo (2006, p. 3):

a segmentação é entendida como uma forma de organizar o turismo para fins de planejamento, gestão e mercado. Os segmentos turísticos podem ser estabelecidos a partir de elementos de identidade da oferta e também das características e variáveis da demanda.

Segundo a OMT, para que um seguimento seja eficaz como ferramenta de marketing, o mesmo deve ser (In Ansarah, 2005, p. 287):

- Mensurável em tamanho e outras variáveis.

- Acessível, por meio de promoção, a canais de distribuição existentes ou potenciais.

- Substancial, grande ou lucrativo o suficiente para servir como mercado-alvo.

- Defensável, em termos de características suficientemente singulares para justificar iniciativas ou programas de marketing específicos que possam enfrentar a abordagem de massa dos concorrentes.

- Durável, mantendo-se com o passar do tempo.

- Competitivo a ponto de seu atendimento proporcionar vantagem sobre a concorrência. 
Sendo para Vaz 1 1999, apud Ansarah, In: Trigo (2005, p. 289), as principais bases de segmentação, com variáveis e estratos mais relevantes são: Segmentação psicográfica, Segmentação comportamental, Segmentação demográfica pessoal, Segmentação demográfica socioeconômica e Segmentação geográfica socioeconômica. As quais estão citadas à baixo:

Segmentação psicográfica (Quadro 1): referências:

- Principal personalidade do consumidor.

- Atitudes, crenças, valores.

- Estilo de vida.

- Modos de expressão.

QUADRO 1 segmentação psicográfica.

\begin{tabular}{|l|l|l|}
\hline \multicolumn{1}{|c|}{ Segmento do mercado } & \multicolumn{1}{|c|}{ Variáveis e extratos } & \multicolumn{1}{c|}{ Bases da segmentação } \\
\hline Turismo Surpresa & Personalidade, estilo de vida & Sociedade, demográfica \\
\hline Turismo de Aventura & Personalidade & Demográfica pessoal, comportamental \\
\hline Turismo espacial & Personalidade & Comportamental, socioeconômica \\
\hline Turismo esportivo & Estilo de Vida & Demográfica pessoal \\
\hline Turismo de Golf & Estilo de Vida, gosto & Comportamental, socioeconômica \\
\hline Turismo Gastronômico & Estilo de Vida (requinte) & Comportamental \\
\hline Enoturismo & Personalidade, gosto & Comportamental \\
\hline Turismo ecológico, rural & Gosto, atitude & Comportamental \\
\hline Turismo de praia & Personalidade, gosto & Geográfica \\
\hline Turismo hidroviário & Estilo de vida & Socioeconômica. \\
\hline
\end{tabular}

Fonte: Vaz (1999), apud Ansarah, In: Trigo. Análise Regionais e Globais do Turismo Brasileiro. São Paulo - SP, 2005. p. 289.

\footnotetext{
${ }^{1}$ VAZ, G. N. Marketing Turístico: Receptivo e Emissivo. São Paulo: Pioneira, 1999.
} 
Segmentação comportamental (Quadro 2): referências:

- Hábitos dos públicos.

- Costumes.

- Tipos de transporte.

- Tipos de acomodação.

QUADRO 2 segmentação comportamental.

\begin{tabular}{|l|l|l|}
\hline Segmento do mercado & \multicolumn{1}{|c|}{ Variáveis e extratos } & \multicolumn{1}{c|}{ Bases da segmentação } \\
\hline Turismo viário & Hábito & Socioeconômica, psicográfica \\
\hline Turismo de resorts & Hábito, ocasião & Socioeconômica, psicográfica \\
\hline Turismo de época & Ocasião & Socioeconômica \\
\hline
\end{tabular}

Fonte: Vaz (1999), apud Ansarah, In: Trigo. Análise Regionais e Globais do Turismo Brasileiro. São Paulo - SP, 2005. p. 289.

Segmentação demográfica pessoal (Quadro 3): referências:

- Identificação básica do cidadão.

- Características físicas

- Características genéticas. 
QUADRO 3 segmentação demográfica pessoal.

\begin{tabular}{|l|l|l|}
\hline \multicolumn{1}{|c|}{ Segmento do mercado } & \multicolumn{1}{|c|}{ Variáveis e extratos } & \multicolumn{1}{c|}{ Bases da segmentação } \\
\hline Turismo infantil & Idade (7 a 13 anos) & Psicográfica, socioeconômica \\
\hline Turismo juvenil & Idade (14 a 19 anos) & Psicográfica, comportamental \\
\hline Turismo da terceira idade & Idade (acima de 55 a 70 anos) & Psicográfica, comportamental \\
\hline Turismo da quarta idade & Idade (acima de 70 anos) & Psicográfica, comportamental \\
\hline Turismo single & Estado civil (solteiro, separado), GLS & Psicográfica, socioeconômica \\
\hline Turismo romântico & Estado civil (casado sem filhos; separado) & Socioeconômica, comportamental \\
\hline Turismo familiar & Estado civil (casado c/ filho) & Socioeconômica \\
\hline Turismo gay & Sexo (orientação sexual) & Psicográfica, socioeconômica \\
\hline Turismo de saúde & Condição física (estético tratamento). & Psicográfica, socioeconômica \\
\hline Turismo para deficiente & Condição física (estética tratamento). & Socioeconômica \\
\hline
\end{tabular}

Fonte: Vaz (1999), apud Ansarah, In: Trigo. Análise Regionais e Globais do Turismo Brasileiro. São Paulo - SP, 2005. p. 289.

Segmentação demográfica socioeconômica (Quadro 4): referências:

- Formação humanística da pessoa.

- Convivência.

- Relacionamento com a sociedade.

QUADRO 4 segmentação demográfica socioeconômica.

\begin{tabular}{|l|l|l|}
\hline \multicolumn{1}{|c|}{ Segmento do mercado } & \multicolumn{1}{|c|}{ Variáveis e extratos } & Bases da segmentação \\
\hline Turismo de estudos & Área de estudos, instrução, especialização & Socioeconômica \\
\hline Turismo cultural & Áreas de estudo & Psicográfica \\
\hline Turismo científico & Área de estudos, instrução, especialização & Psicográfica, socioeconômica \\
\hline Turismo de intercâmbio & Área de estudos & Psicográfica, socioeconômica \\
\hline Turismo pedagógico & Área de estudos, instrução, especialização & Psicográfica, socioeconômica \\
\hline Turismo religioso & Afiliação religiosa, filosófica & Psicográfica \\
\hline Turismo familiar & Etnia, ancestralidade & Demográfica pessoal \\
\hline
\end{tabular}

Fonte: Vaz (1999), apud Ansarah, In: Trigo. Análise Regionais e Globais do Turismo Brasileiro. São Paulo - SP, 2005. p. 290. 
Segmentação geográfica socioeconômica (Quadro 5): referências:

- Características quanto às pessoas num bairro.

- Cidade.

- Estado ou país.

- Aglomerações ou outras divisões.

QUADRO 5 segmentação geográfica socioeconômica.

\begin{tabular}{|l|l|l|}
\hline \multicolumn{1}{|c|}{ Segmento do mercado } & \multicolumn{1}{|c|}{ Variáveis e extratos } & \multicolumn{1}{c|}{ Bases da segmentação } \\
\hline Turismo de eventos & Ocupação profissional & Socioeconômica, coportamental \\
\hline & Atividade cultural & Psicográfica, socioeconômica \\
\hline Turismo de negócios & Atividade econômica & Comportamental \\
\hline Turismo comercial & Setor empresarial & Comportamental \\
\hline Turismo de incentivo & Setor empresarial, área funcional Sacio cultural, psicográfica \\
\hline Turismo social & Nível de renda (baixa renda). & Comportamental \\
\hline
\end{tabular}

Fonte: Vaz (1999), apud Ansarah, In: Trigo. Análise Regionais e Globais do Turismo Brasileiro. São Paulo - SP, 2005. p. 290.

Para Zardo (2003, p.157), “a determinação de um perfil de consumidores que se pretenderá atingir é muito importante para a definição dos meios que serão utilizados para a promoção ou comunicação do nosso produto".

Kotler (2000, p. 30) crê que, "para cada mercado-alvo escolhido, a empresa desenvolve uma oferta de mercado. A oferta é posicionada na mente dos compradores-alvo como possuidora de algum(ns) benefício(s) fundamental(ais) (...)". 


\subsection{Posicionamento}

Para Kotler (1997), apud Hooley, et al. (2001), posicionamento é o ato de fazer o projeto da oferta e imagem da empresa de forma que ela ocupe uma posição competitiva significativa e distrital nas mentes dos clientes-alvo.

Posicionamento para Kotler (2000, p.321), "é o ato de desenvolver a oferta e a imagem da empresa para ocupar um lugar destacado na mente dos clientes-alvo".

O posicionamento competitivo para Hooley, et al. (2001, p.177), "trata-se de como os clientes percebem as ofertas alternativas no mercado, comparadas às outras".

Zardo (2003), afirma que embora muitos estudiosos compreendam o posicionamento como uma forma de promoção, consideram-no apenas como a colocação de determinado produto/serviço em um certo patamar de mercado; esquecendo que o posicionamento é a idealização da imagem de algum produto/serviço, da própria empresa ou do destino turístico, pelos clientes. Ainda para Zardo (2003, p. 52), "posicionamento é o que se faz na mente do cliente em perspectiva. Ou seja, você posiciona o produto na mente do comprador em potencial, seja o próprio turista ou as pessoas do ambiente do entorno".

Middleton (2002, p.217), assinala que:

O posicionamento sustenta o crescimento do mercado/produto através da criação e sustentação de uma imagem favorável ou percepção a longo prazo entre clientes potenciais (...), de quem depende a lucratividade futura de um negócio.

"Para criar uma imagem turística é preciso causar impactos positivos, relevantes e de credibilidade, de sorte a fazer penetrar na mente dos turistas atributos que os atraiam a essa localidade". (TRIGUEIRO, 2001, p.46). No entanto, para Trigueiro (2001, p.46) "a imagem turística, um conjunto de idéias e impressões sobre um local".

A imagem para Kotler (2000, p.318), "é a maneira como o público vê a empresa ou seus produtos". 
O posicionamento precisa ser forte e claro para que seja evitado erros de posicionamento que podem acabar com a estratégia de marketing. Kotler (2000, p.323) enumera os quatro principais erros de posicionamento:

- Subposicionamento: algumas empresas descobrem que os compradores têm apenas uma vaga idéia da marca;

- Superposicionamento: os compradores podem ter uma imagem demasiadamente estreita de uma marca;

- Posicionamento confuso: os compradores podem possuir uma imagem confusa da marca, que resulta de um excesso de alegações ou de mudanças muito freqüentes no posicionamento;

- Posicionamento duvidoso: os compradores podem achar difícil acreditar no que a marca alega possuir, tendo em vista as características, o preço ou o fabricante do produto.

O posicionamento possui diferentes estratégias, como enfoca Kotler (2000, p. 323-324):

- Posicionamento por atributo: uma empresa se posiciona com base em um atributo, como tamanho ou tempo de existência;

- Posicionamento por benefício: o produto é posicionado como líder em um certo benefício;

- Posicionamento por aplicação ou utilização: posicionamento do produto como o melhor para algum uso ou aplicação;

- Posicionamento por usuário: posicionamento do produto como o melhor para algum grupo de usuários;

- Posicionamento por concorrente: alega-se que o produto é de algum modo melhor que o do concorrente; 
- Posicionamento por categorias de produtos: o produto é posicionado como líder em uma determinada categoria de produtos;

- Posicionamento por qualidade ou preço: o produto é posicionado como o que oferece o melhor valor.

Entretanto, para Hooley, et al. (2001, p. 181):

o posicionamento trata de entender como os clientes comparam as ofertas alternativas no mercado e construir estratégias que descrevem aos clientes como as ofertas da empresa diferem de maneiras importantes daquelas de concorrentes existentes ou potenciais.

Hooley, et al. (2001), afirma que junto com a segmentação de mercado, o posicionamento é de grande relevância para o desenvolvimento de estratégias de marketing. 


\section{METODOLOGIA}

O trabalho realizado foi uma pesquisa descritiva quantitativa, por se tratar de um levantamento de informações relevantes no que tange ao turismo e comércio local e, também, por ser viável somente com o contato direto com os turistas.

Para Oliveira (2000, p. 68):

a técnica como complemento do método no trabalho científico pode ser definida como modo de realizar uma atividade, arte e ofício de maneira hábil, segura e perfeita. Trata-se da ação operacional e tática. É o ato de fazer acontecer.

Segundo Dencker (2001, p. 124):

A pesquisa descritiva em geral procura descrever fenômenos ou estabelecer relações entre variáveis. Utiliza técnicas padronizadas de coleta de dados como o questionário e a observação sistêmica. A forma mais comum de apresentação é o levantamento, em geral realizado mediante questionário e que oferece uma descrição da situação no momento da pesquisa.

Oliveira (2000, p.68) afirma que "o método quantitativo na pesquisa científica está sempre associado à experimentação e manipulação de um objeto estudado em uma população ou universo".

Para Oliveira (2000), por ser impossível se estudar todo o universo, por diversas limitações como: de recursos técnicos, humanos, financeiros, entre outros; a pesquisa cientifica trabalha com a amostra.

Segundo Marconi, et al. (1988, p.37), "universo ou população: é o conjunto de seres animados ou inanimados que apresentam pelo menos uma característica em comum [...]". Sendo que amostra "é uma porção ou parcela, convenientemente selecionado do universo (população); é um subconjunto do universo [...]". 
Marconi e Lakatos (1988, p. 37):

O universo ou população de uma pesquisa depende do assunto a ser investigado, e a amostra, porção ou parcela do universo, que realmente será submetida à verificação, é obtida ou determinada por técnica específica de amostragem.

Há duas grandes divisões no processo de amostragem (determinação da amostragem a ser pesquisada): a probabilística e a nãoprobabilistica.

Para a realização dessa pesquisa utilizou-se uma amostra probabilística aleatória simples, pois cada elemento da população tem a uma chance determinada de ser selecionado. Assim, para Dencker (2001, p. 176), a amostra probabilística simples "é escolhida de forma que todas as amostras tenham uma probabilidade conhecida e igual de serem selecionadas. Todos os componentes do universo devem ter igual oportunidade de participar da amostra".

Segundo a Secretaria de Estado do Turismo do Distrito Federal, em pesquisa sobre o Turismo Receptivo no Distrito Federal, apresentada no ano de 2005 (números retirados com ano base 2005), Brasília recebeu um total de 936150 (novecentos e trinta e seis mil e cento e cinqüenta) visitantes; sendo destes 31500 (trinta e um mil e quinhentos) visitantes estrangeiros.

Assim, devido ao número de visitantes recebidos e levando em conta que a pesquisa foi realizada apenas com os visitantes domésticos, foi estabelecido segundo a metodologia de Antonio Carlos Gil, que a amostra é infinita na qual determina o número de 400 pessoas. Sendo o cálculo de amostra para população infinita é estabelecido pela seguinte fórmula:

$$
n=\frac{\sigma^{2} p . q}{e^{2}}
$$


Onde "n" é a amostra, " $\sigma$ " variância. A Raiz da variância forneceu o desvio padrão que é 2, "p" é 50 e "q" é 50 e "e2" é o erro máximo permitido em ciências sociais, que equivale a $5 \%$.

Porém, apenas 315 questionários retornaram respondidos, o que fez com que o caráter da amostragem tornasse a amostra não-probabilística por acessibilidade e conveniência.

\subsection{Instrumento e Coleta de dados}

Dencker (2001, p.137) afirma que:

A coleta de dados é a fase do método de pesquisa que tem por objetivo obter informações sobre a realidade. Conforme as informações necessárias, existem diversos instrumentos e formas de operá-los. Nas ciências humanas, o questionário e a entrevista são os mais freqüentes e possuem em comum o fato de serem constituídos de uma lista de indagações que se respondidas, dão ao pesquisador a informação necessária.

Os instrumentos de coleta de dados são, para Marconi, et al. (1988), definidos de acordo com as circunstâncias ou com o tipo de investigação. Sendo entrevista, questionário, coleta documental, observação, formulário, medidas de opiniões e atitudes, técnicas mercadológicas, testes, sociometria, análise de conteúdo e história da vida, consideradas técnicas de investigação.

A técnica de coleta de dados adotada foi a entrevista. Pois para Marconi e Lakatos (1998, p. 70):

A entrevista é um encontro entre duas pessoas, a fim de que uma delas obtenha informações a respeito de determinado assunto, mediante uma conversação de natureza profissional. É um procedimento utilizado na investigação social, para a coleta de dados ou para ajudar no diagnóstico ou no tratamento de um problema social. 
Para Goode e Hatt (1969) apud Marconi e Lakatos, (1988, p. 70), a entrevista "consiste no desenvolvimento de precisão, focalização, fidedignidade e validade de um certo ato social como a conversação".

A entrevista para Dencker (2001, p.137), "tem uma relação assimétrica, já que as relações pessoais do pesquisador e do entrevistado são um processo bidirecional ou de influência mútua entre as pessoas. As perguntas são feitas oralmente e as respostas registradas pelo pesquisador".

Sendo o instrumento de coleta de dados adotado para realização desta pesquisa foi o questionário (ver Apêndice A), pois para Dencker (2001, p. 146), "a finalidade do questionário é obter, de maneira sistêmica e ordenada, informações sobre as variáveis que intervêm em uma investigação, em relação a uma população ou amostra determinada".

Para Marconi e Lakatos (1988, p. 74), "questionário é um instrumento de coleta de dados, constituído por uma série ordenada de perguntas, que devem ser respondidas por escrito e sem a presença do entrevistador [...]".

Sendo, segundo as afirmações citadas, o melhor e/ou mais adequado instrumento para a feição do trabalho de pesquisa.

Para o plano de tratamento dos dados da pesquisa, do qual é um estudo quantitativo, foi utilizado o plano de estatística descritiva com uso do Statistical Package for Social Sciences - SPSS, que em português significa pacote estatístico para ciências sociais. O SPSS é um software estatístico, usado em estatísticas inferênciais e descritivas. 


\title{
4. APRESENTAÇÃO E ANÁLISE DOS RESULTADOS
}

Nesse capítulo será apresentado as análises e os resultados da pesquisa realizada através da aplicação de questionário para uma amostra de 315 (trezentos e quinze) pessoas em toda cidade.

Para Hooley, et al. (2001, p. 183):

\begin{abstract}
"As questões mais importantes nos estudos de segmentação giram em torno das bases nas quais a segmentação deve ser conduzida e o número de segmentos relevantes para um mercado específico. A seleção de bases para a segmentação é crucial para obter uma imagem clara da natureza do mercado"[...]
\end{abstract}

Ainda para Hooley, et al. (2001), as variáveis utilizadas para segmentar os mercados podem ser reunidas em três classes principais:

- Características básicas do cliente

- Atitudes do cliente

- Comportamento do cliente

De acordo com Hooley, et al. (2001), as principais características objetivas do cliente para segmentar o mercado são as demográficas (sexo, idade, geografia, subcultura) e Socioeconômicas (ocupação, renda, educação).

Assim, relacionando os dados da pesquisa com a adoção da teoria acima citada serão, elencadas as principais características e as freqüências dos visitantes em Brasília. 


\subsection{Análise descritiva}

Dentre os 315 (trezentos e quinze) questionários aplicados, observou-se que o perfil dos visitantes entrevistados corresponde a um maior público do gênero masculino, com idade (independentemente do gênero) entre 18 a 29 anos e são solteiros. Sendo a região Sudeste a principal emissora de turistas à Brasília. Ainda sobre os entrevistados, notou-se que a maioria são funcionários privados, possuem nível superior completo e um nível de renda confortável.

Gráfico 1: Gênero

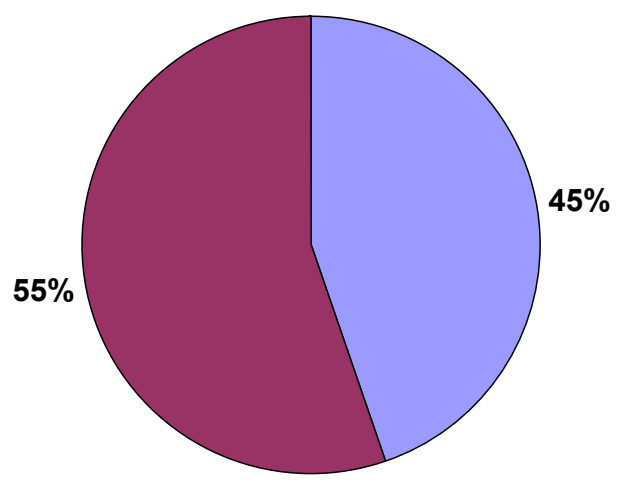

De acordo com a pesquisa, descobriu-se que o número de visitantes do gênero masculino sobressai-se em relação ao feminino. Pois, como mostra o gráfico a diferença representa um percentual de $10 \%$ a mais. 
Gráfico 2 : Idade

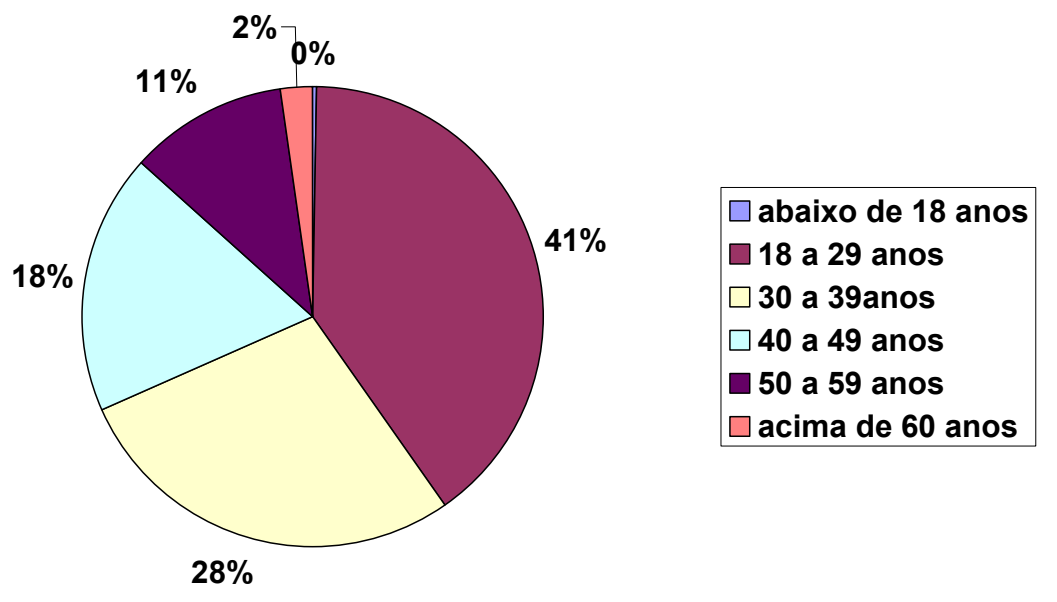

Analisando a freqüência dos visitantes, percebe-se que a maioria do público entrevistado pertence a uma faixa etária mais jovem compreendida entre 18 a 29 anos.

Gráfico 3: Região de origem

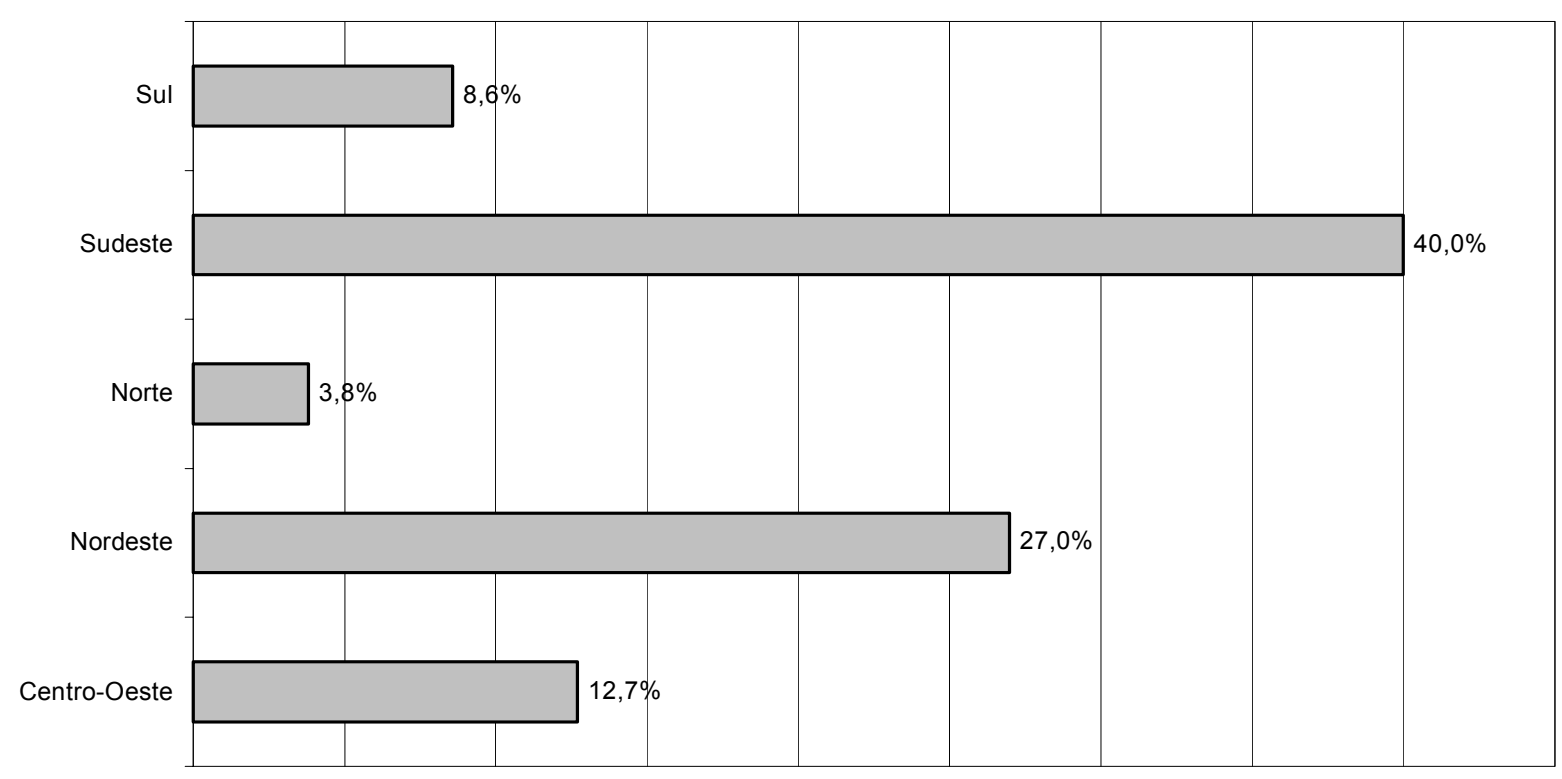


Como ilustra o gráfico, concluiu-se que a parte mais representativa da freqüência dos entrevistados $40 \%$ partem da Região Sudeste do País, seguida pela região Nordeste com $27 \%$.

Gráfico 4: Estado civil
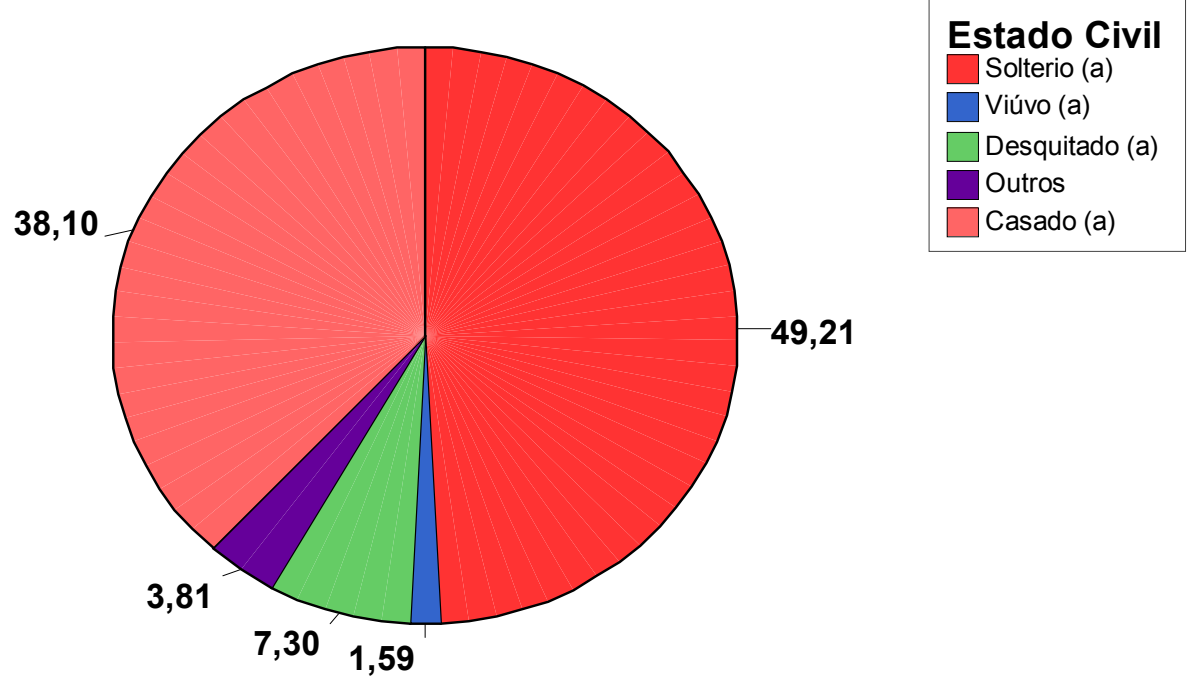

49,21

Com relação à totalidade da freqüência dos entrevistados, $49,21 \%$ do público visitante de Brasília é composto por pessoas solteiras, seguido por $38,10 \%$ por pessoas casadas e $12,7 \%$ é formado por pessoas viúvas, desquitadas ou não quiseram declarar. 


\subsubsection{Características socioeconômicas}

Gráfico 5: Ocupação

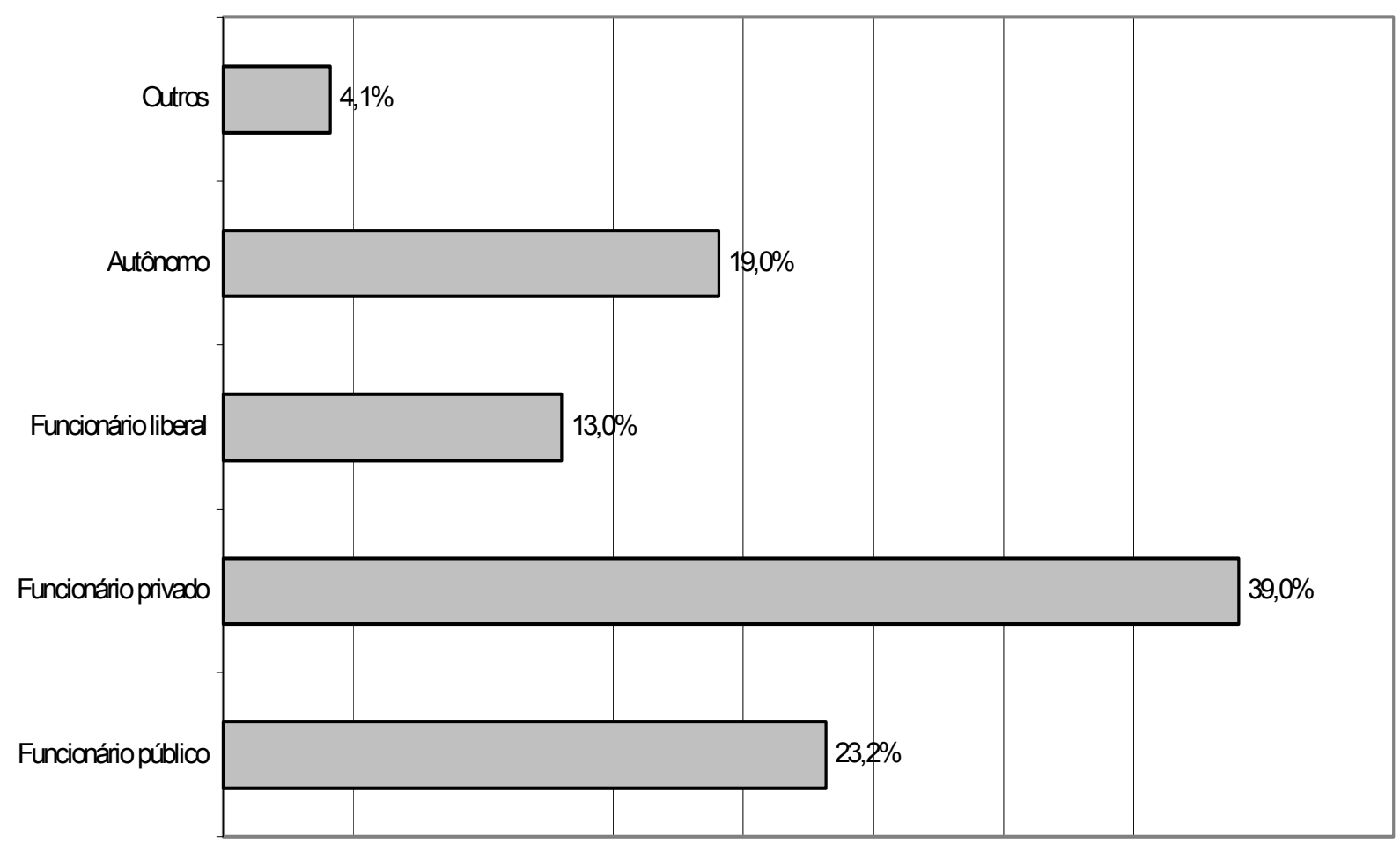

Ao examinar os dados sobre ocupação, percebeu-se que dentre os entrevistados, 39\% são funcionários de empresas privado, seguido de $23,2 \%$ de funcionários públicos. 
Gráfico 6: Renda

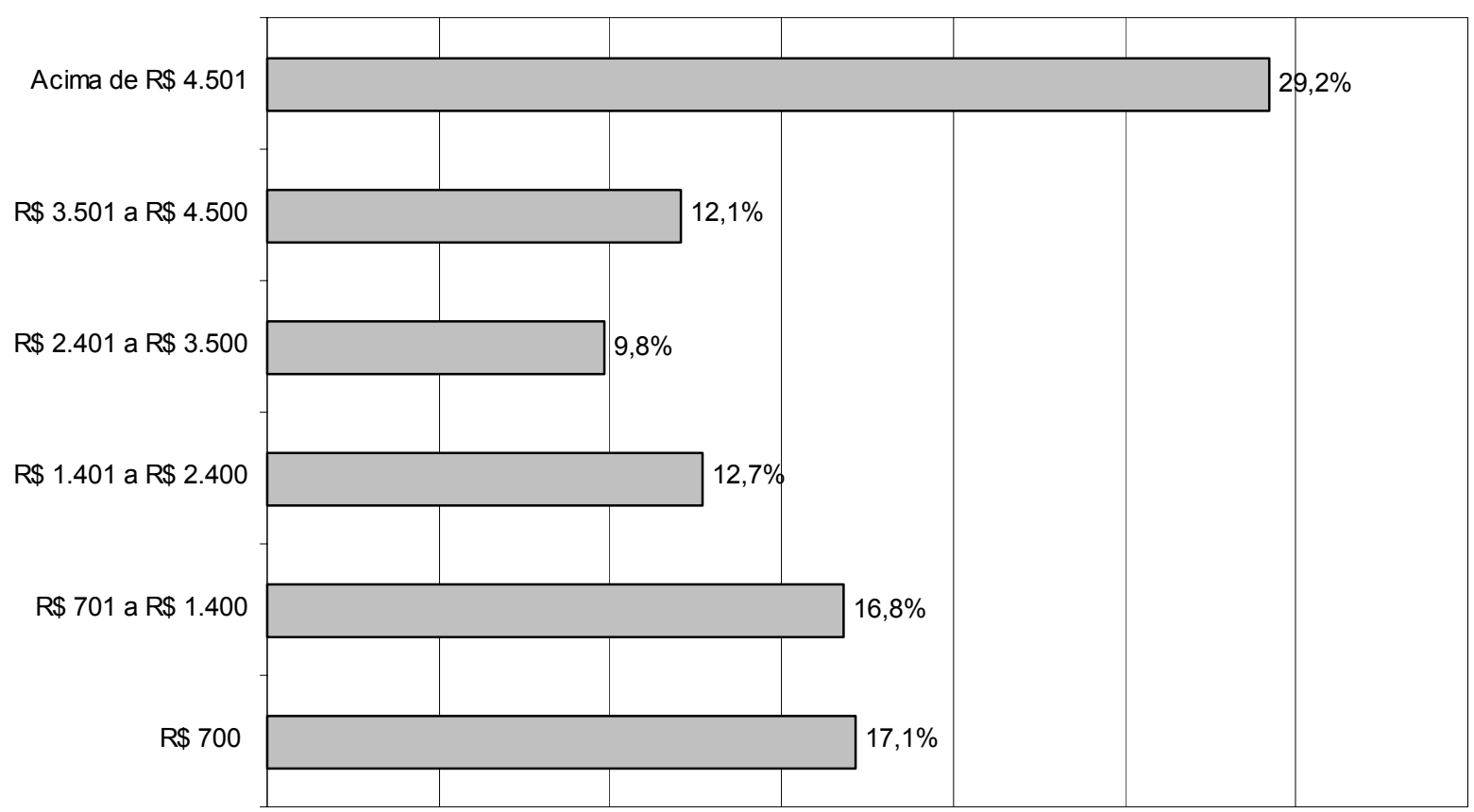

Observa-se que a freqüência mais expressiva dos visitantes em Brasília tem renda superior a $\mathrm{R} \$ 4.501,00$ (quatro mil quinhentos e hum reais), o que demonstra o elevado poder de consumo de bens e serviços oferecidos pela cidade por iniciativas públicas e privadas.

\section{Gráfico 7: Escolaridade}

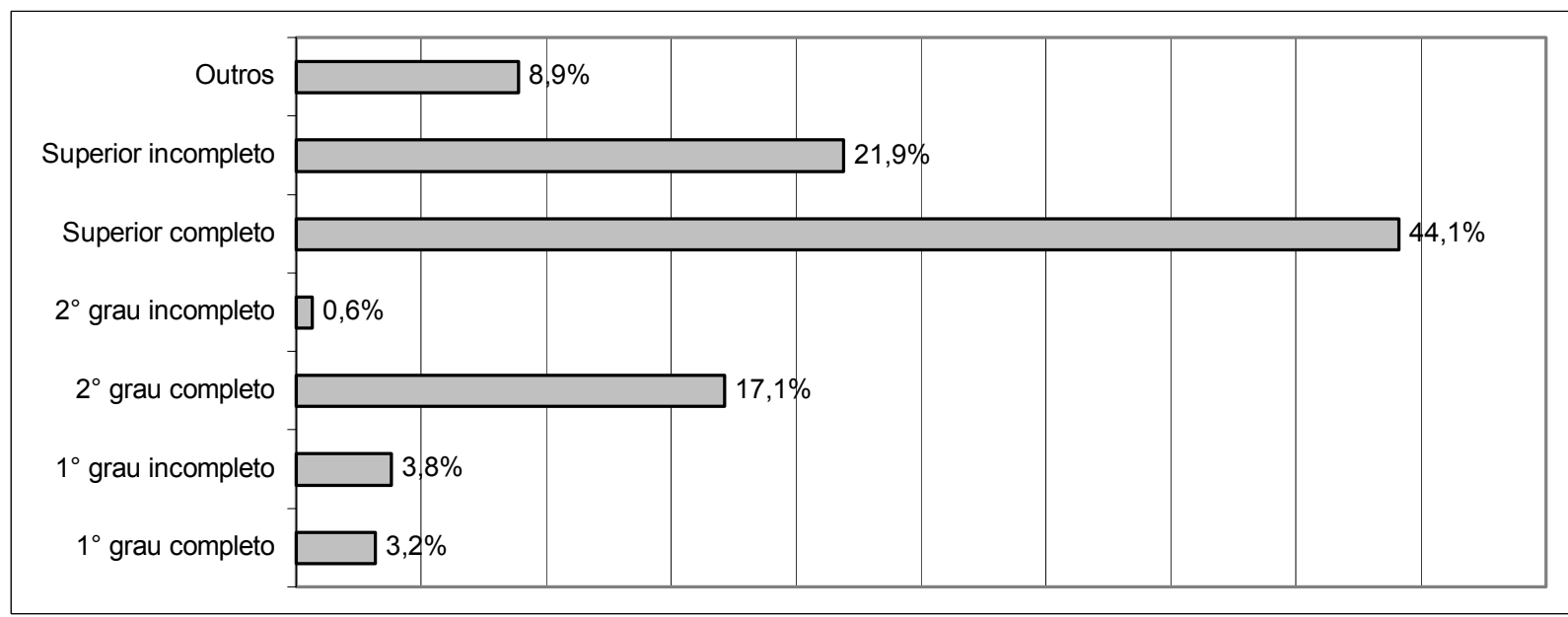


Ao interpretar o Gráfico 7, somando as freqüências dos visitantes com nível superior completo, incompleto e outros (pós-graduados e doutores), percebe-se que grande parte do público pertence a esse nível. O que também leva a crer que o público passa a ser exigente e cauteloso.

4.1.3 Cruzamentos significativos

- Gênero x Motivo da viagem

\begin{tabular}{|c|c|c|c|c|c|c|c|c|c|c|c|}
\hline & \multicolumn{10}{|c|}{ Motivo da viagem } & \multirow[b]{2}{*}{ Total } \\
\hline & Política & Jegócios & sonvençõef & Eventos & Lazer & Outros & \begin{tabular}{|c|} 
Turismo \\
Cívico
\end{tabular} & $\begin{array}{l}\text { Turismo } \\
\text { le Saúde? }\end{array}$ & \begin{tabular}{|l} 
Turismo \\
Zeligioso
\end{tabular} & $\begin{array}{l}\text { Turismo } \\
\text { Místico }\end{array}$ & \\
\hline Sexc Feminino Frequênc & 2 & 36 & 10 & 5 & 57 & 23 & 3 & 6 & 4 & 3 & 141 \\
\hline Porcentad & 1,4 & 25,5 & 7,1 & 3,5 & 40,4 & 16,3 & 2,1 & 4,3 & 2,8 & 2,1 & 100,0 \\
\hline Masculinc Frequênc & 6 & 87 & 14 & 8 & 27 & 41 & 0 & 2 & 0 & 0 & 173 \\
\hline Porcentad & 3,5 & 50,3 & 8,1 & 4,6 & 15,6 & 23,7 & ,0 & 1,2 & 0 & ,0 & 100,0 \\
\hline Tota Frequência & 8 & 123 & 24 & 13 & 84 & 64 & 3 & 8 & 4 & 3 & 314 \\
\hline Porcentagem & 2,5 & 39,2 & 7,6 & 4,1 & 26,8 & 20,4 & 1,0 & 2,5 & 1,3 & 1,0 & 100,0 \\
\hline
\end{tabular}

Ao analisar esse cruzamento, aparentemente notou-se que o principal motivo da viagem para o público feminino corresponde a lazer. Enquanto o gênero masculino prioriza negócios. Pois, como mostra o cruzamento $50,3 \%$ do público masculino vêm a negócios e apenas $25,5 \%$ do gênero feminino vem pelo mesmo motivo. Entretanto, $40,4 \%$ do gênero feminino, contra $15,6 \%$ do público masculino veio a lazer.

- Gênero x Quantas vezes o Senhor (a) esteve na cidade

\begin{tabular}{|c|c|c|c|c|c|c|c|c|}
\hline & \multicolumn{5}{|c|}{ Quantas vezes o senhor (a) esteve na cidade? } & \multirow{2}{*}{$\begin{array}{r}\text { Total } \\
1\end{array}$} \\
\hline \multirow{5}{*}{ Sexo } & & & \begin{tabular}{l|l}
1 \\
\end{tabular} & 2 & 3 & 4 & Mais de 4 & \\
\hline & Feminino & Frequência & 33 & 23 & 21 & 5 & 58 & 140 \\
\hline & & Percentual & $23,60 \%$ & $16,40 \%$ & $15,00 \%$ & $3,60 \%$ & $41,40 \%$ & $100,00 \%$ \\
\hline & Masculino & Frequência & 29 & 20 & 9 & 13 & 103 & 174 \\
\hline & & Percentual & $16,70 \%$ & $11,50 \%$ & $5,20 \%$ & $7,50 \%$ & $59,20 \%$ & $100,00 \%$ \\
\hline \multirow[t]{2}{*}{ Total } & & Frequência & 62 & 43 & 30 & 18 & 161 & 314 \\
\hline & & Percentual & $19,70 \%$ & $13,70 \%$ & $9,60 \%$ & $5,70 \%$ & $51,30 \%$ & $100,00 \%$ \\
\hline
\end{tabular}


Conforme esse cruzamento, aparentemente nota-se que o gênero masculino volta à cidade com mais freqüência. Pois, apenas $16,70 \%$ do público masculino entrevistado veio 1 vez à Brasília, contra 23,60\% do público feminino. Sendo, também, mais freqüente o percentual de pessoas do gênero masculino, 59,20\%, que estiveram na cidade mais de quatro vezes.

Gráfico 8: Transporte utilizado

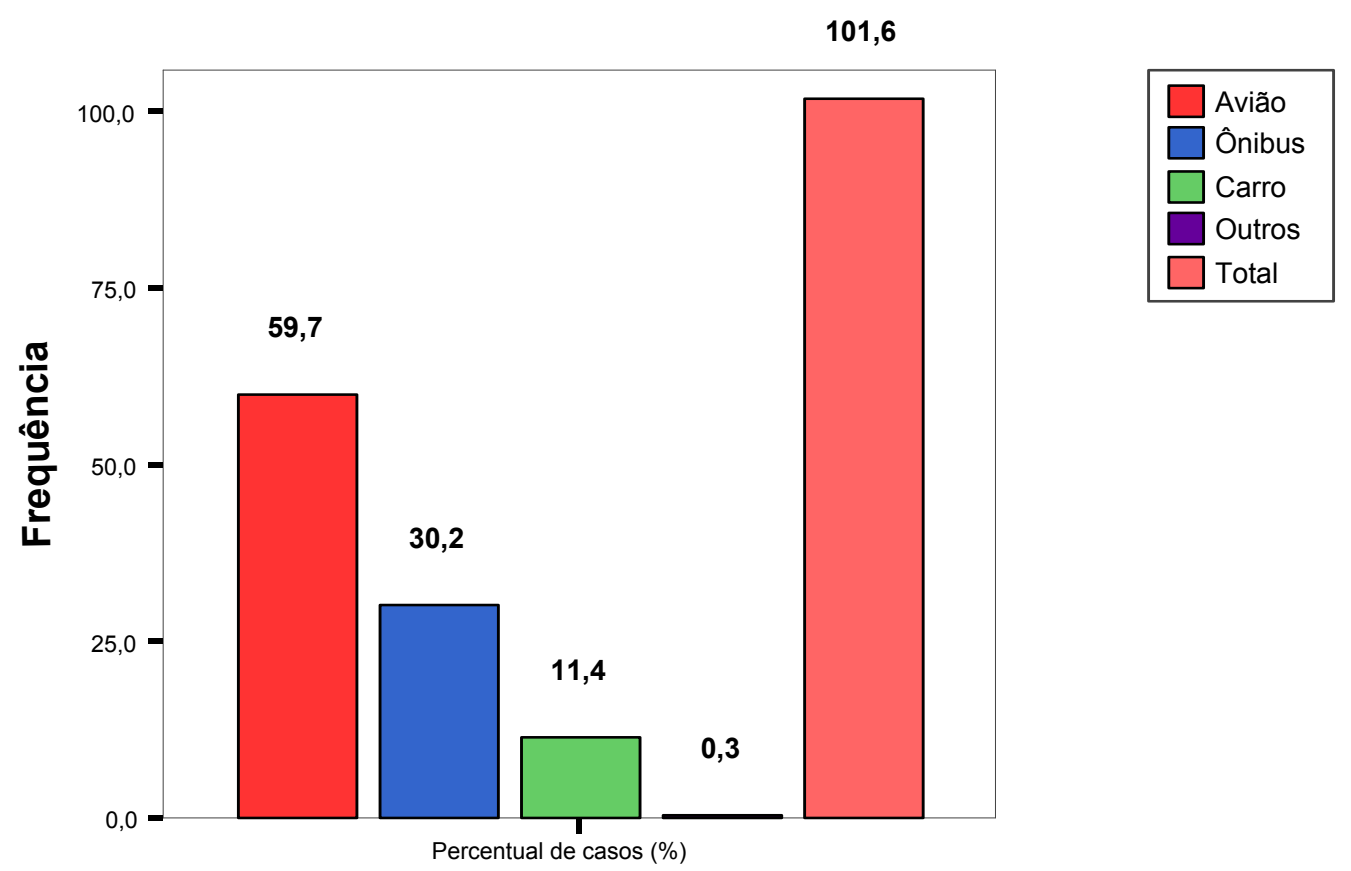

Em relação ao transporte utilizado, percebe-se que mais de $50 \%$ do universo total da pesquisa optou pelo aéreo, contrapondo-se $30,02 \%$ que utilizou carro. 
Gráfico 9: O (a) senhor (a) voltaria a Brasília?

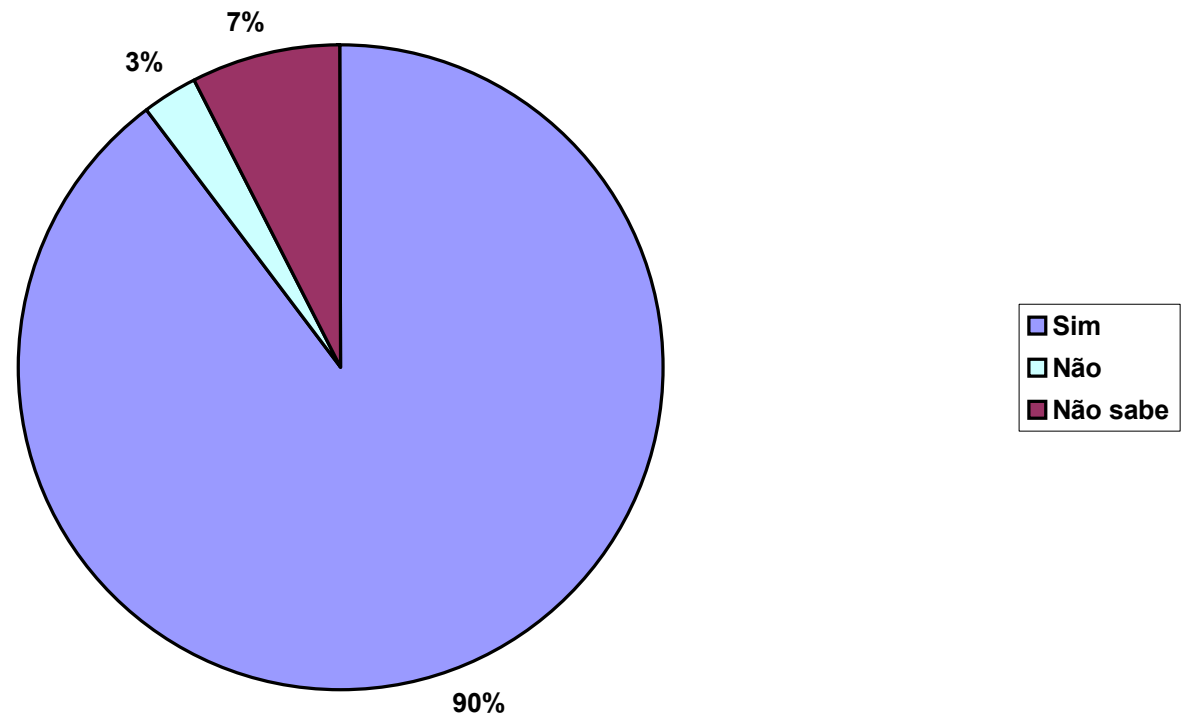

Também, constatou-se que entre o total dos visitantes entrevistados (sem distinção de gênero) a grande maioria demonstra sua intimidade com a cidade (independentemente o motivo da viagem), pois $90 \%$ dos turistas voltariam à Brasília. Enquanto os outros $10 \%$ não ou não sabem se voltam. 
- Idade x Local de hospedagem

\begin{tabular}{|c|c|c|c|c|c|c|c|c|}
\hline & \multicolumn{5}{|c|}{ Onde se hospedou? } & \multirow[b]{2}{*}{ Total } \\
\hline & & & Hotel & Pousada & $\begin{array}{c}\text { Casa de } \\
\text { parente/a } \\
\text { migo }\end{array}$ & Albergue & Outros & \\
\hline \multirow{12}{*}{$\begin{array}{l}\text { Faixa } \\
\text { Etária }\end{array}$} & \multirow[t]{2}{*}{18 a 29 anos } & Frequência & 34 & 3 & 85 & 1 & 1 & 123 \\
\hline & & Porcentagem & 27,6 & 2,4 & 69,1 & ,8 & 8 & 100,0 \\
\hline & \multirow[t]{2}{*}{30 a 39 anos } & Frequência & 41 & 4 & 37 & 1 & 2 & 84 \\
\hline & & Porcentagem & 48,8 & 4,8 & 44,0 & 1,2 & 2,4 & 100,0 \\
\hline & \multirow[t]{2}{*}{40 a 49 anos } & Frequência & 33 & 3 & 19 & 0 & 0 & 55 \\
\hline & & Porcentagem & 60,0 & 5,5 & 34,5 & , 0 & 0 & 100,0 \\
\hline & \multirow[t]{2}{*}{50 a 59 anos } & Frequência & 23 & 1 & 12 & 0 & 1 & 35 \\
\hline & & Porcentagem & 65,7 & 2,9 & 34,3 & 0 & 2,9 & 100,0 \\
\hline & \multirow{2}{*}{$\begin{array}{l}\text { acima de } 60 \\
\text { anos }\end{array}$} & Frequência & 3 & 0 & 3 & 0 & 0 & 6 \\
\hline & & Porcentagem & 50,0 & , 0 & 50,0 & 0 & , 0 & 100,0 \\
\hline & \multirow{2}{*}{$\begin{array}{l}\text { abaixo de } 18 \\
\text { anos }\end{array}$} & Frequência & 0 & 0 & 1 & 0 & 0 & 1 \\
\hline & & Porcentagem & 0 & ,0 & 100,0 & 0 & , 0 & 100,0 \\
\hline \multirow[t]{2}{*}{ Total } & \multicolumn{2}{|l|}{ Frequência } & 134 & 11 & 157 & 2 & 4 & 304 \\
\hline & \multicolumn{2}{|l|}{ Porcentagem } & 44,1 & 3,6 & 51,6 & ,7 & 1,3 & 100,0 \\
\hline
\end{tabular}

Ao cruzar essas variáveis, aparentemente concluiu-se que além da freqüência dos visitantes com idade entre 18 a 29 anos ser maior, percebeu-se que $69,1 \%$ desse público hospedou-se em casa de parente/amigo. Enquanto que as pessoas compreendidas nas outras faixas etárias preferem hotel. Pois, como enfatiza o cruzamento, as pessoas entre 30 a 39 anos correspondem a um percentual de $48,8 \%$, seguidas pelo público entre 40 a 49 anos alcançando uma porcentagem de $60 \%$ e a maioria dos entrevistados entre 50 a 59 anos corresponde a $65,7 \%$. 
- Região de origem dos visitantes x Motivo da viagem

\begin{tabular}{|c|c|c|c|c|c|c|c|c|c|c|c|c|c|}
\hline & \multicolumn{10}{|c|}{ Motivo da viagem } & \multirow[b]{2}{*}{ Total } \\
\hline & & & \multirow{2}{*}{\begin{tabular}{|r} 
Política \\
1
\end{tabular}} & \multirow{2}{*}{$\frac{\text { Negócios }}{15}$} & \multirow{2}{*}{ fonvençõe } & \multirow{2}{*}{$\begin{array}{r}\text { Eventos } \\
0\end{array}$} & \multirow{2}{*}{$\frac{\text { Lazer }}{14}$} & \multirow{2}{*}{\begin{tabular}{|r} 
Outros \\
6
\end{tabular}} & \multirow{2}{*}{$\begin{array}{r}\begin{array}{c}\text { Turismo } \\
\text { Cívico }\end{array} \\
0\end{array}$} & \multirow{2}{*}{$\begin{array}{r}\begin{array}{l}\text { Turismo } \\
\text { de Saúde }\end{array} \\
2\end{array}$} & \multirow{2}{*}{\begin{tabular}{|c|} 
Turismo \\
Religioso \\
0
\end{tabular}} & \multirow{2}{*}{\begin{tabular}{|r} 
Turismo \\
Místico \\
2
\end{tabular}} & \\
\hline Qual c & Centro-O€ & :Frequência & & & & & & & & & & & 40 \\
\hline sua & & Porcentag & 2,5 & 37,5 & 7,5 &, 0 & 35,0 & 15,0 & ,0 & 5,0 & ,0 & 5,0 & 100,0 \\
\hline cidade & Nordeste & Frequênci- & 3 & 21 & 5 & 4 & 33 & 19 & 0 & 4 & 2 & 0 & 85 \\
\hline $\begin{array}{l}\text { de } \\
\text { oriaen }\end{array}$ & & Porcentag & 3,5 & 24,7 & 5,9 & 4,7 & 38,8 & 22,4 & , 0 & 4,7 & 2,4 & , 0 & 100,0 \\
\hline & Norte & Frequência & 1 & 2 & 1 & 1 & 5 & 2 & 0 & 1 & 0 & 0 & 12 \\
\hline & & Porcentag & 8,3 & 16,7 & 8,3 & 8,3 & 41,7 & 16,7 & 0 & 8,3 & 0 & 0 & 100,0 \\
\hline & Sudeste & Frequência & 1 & 64 & 11 & 8 & 21 & 24 & 1 & 0 & 1 & 1 & 125 \\
\hline & & Porcentag & ,8 & 51,2 & 8,8 & 6,4 & 16,8 & 19,2 & ,8 & 0 & ,8 & , 8 & 100,0 \\
\hline & Sul & Frequência & 0 & 13 & 0 & 0 & 4 & 12 & 0 & 0 & 0 & 0 & 27 \\
\hline & & Porcentag & 0 & 48,1 & 0 & , 0 & 14,8 & 44,4 & 0 & 0 & 0 &, 0 & 100,0 \\
\hline & Exterior & Frequência & 1 & 1 & 1 & 0 & 0 & 0 & 0 & 0 & 0 & 0 & 3 \\
\hline & & Porcentag & 33,3 & 33,3 & 33,3 &, 0 & 0 & , 0 & , 0 & 0 & ,0 & , 0 & 100,0 \\
\hline Total & Frequênci & & 7 & 116 & 21 & 13 & 77 & 63 & 1 & 7 & 3 & 3 & 292 \\
\hline & Porcentag & & 2,4 & 39,7 & 7,2 & 4,5 & 26,4 & 21,6 & , 3 & 2,4 & 1,0 & 1,0 & 100,0 \\
\hline
\end{tabular}

Como referenciado no cruzamento acima, aparentemente o principal motivo da viagem para os visitantes da região centro-oeste com $37,5 \%$, região sudeste com $51,2 \%$, e da região sul com $48,1 \%$, foi "negócios". Enquanto que para os visitantes da região nordeste com $38,8 \%$ e da região norte com $41,7 \%$, foi "lazer".

- Ocupação x À que o (a) senhor (a) relaciona Brasília - Ocupação x Motivo de viagem

\begin{tabular}{|c|c|c|c|c|c|c|c|c|c|c|c|c|c|}
\hline & \multicolumn{10}{|c|}{ À que o senhor (a) relaciona Brasília? } & \multirow[b]{2}{*}{ Total } \\
\hline & & & & legócio & onvençõ & Eventos & \multirow{2}{*}{\begin{tabular}{|l} 
Lazer \\
4
\end{tabular}} & \multicolumn{4}{|c|}{$\begin{array}{l}\text { Turismo TurismoTurismo Turismo } \\
\text { Cívico e SaúdkeligiosdMístico }\end{array}$} & Outros & \\
\hline \multirow{10}{*}{$\begin{array}{l}\text { Qual SL } \\
\text { ocupaç } \\
\text { atual? }\end{array}$} & Funcioná & Frequêng & & 20 & 8 & 11 & & 7 & 1 & $\begin{array}{l}0 \\
\end{array}$ & 4 & 1 & 73 \\
\hline & público & Porcenta & 75,3 & 27,4 & 11,0 & 15,1 & 5,5 & 9,6 & 1,4 & , 0 & 5,5 & 1,4 & 100,0 \\
\hline & Funcioná & Frequênd & 87 & 41 & 11 & 12 & 17 & 15 & 1 & 1 & 1 & 8 & 122 \\
\hline & priva & Porcenta & 71,3 & 33,6 & 9,0 & 9,8 & 13,9 & 12,3 & ,8 & ,8 & ,8 & 6,6 & 100,0 \\
\hline & Profissior & Frequên & 36 & 12 & 6 & 6 & 2 & 1 & 0 & 1 & 1 & 2 & 41 \\
\hline & Liberal & Porcenta & 87,8 & 29,3 & 14,6 & 14,6 & 4,9 & 2,4 & , 0 & 2,4 & 2,4 & 4,9 & 100,0 \\
\hline & Autônomı & Frequênd & 38 & 19 & 4 & 6 & 1 & 3 & 1 & 1 & 2 & 3 & 60 \\
\hline & & Porcenta & 63,3 & 31,7 & 6,7 & 10,0 & 1,7 & 5,0 & 1,7 & 1,7 & 3,3 & 5,0 & 100,0 \\
\hline & Outros & Frequêng & 7 & 6 & 3 & 2 & 3 & 2 & 1 & 0 & 0 & 1 & 13 \\
\hline & & Porcenta & 53,8 & 46,2 & 23,1 & 15,4 & 23,1 & 15,4 & 7,7 &, 0 &, 0 & 7,7 & 100,0 \\
\hline \multirow[t]{2}{*}{ Total } & Frequênci & & 214 & 96 & 29 & 37 & 27 & 28 & 4 & 3 & 8 & 15 & 300 \\
\hline & Porcentag & yem & 71,3 & 32,0 & 9,7 & 12,3 & 9,0 & 9,3 & 1,3 & 1,0 & 2,7 & 5,0 & 100,0 \\
\hline
\end{tabular}




\begin{tabular}{|c|c|c|c|c|c|c|c|c|c|c|c|c|c|}
\hline & \multicolumn{10}{|c|}{ Motivo da viagem } & \multirow[b]{2}{*}{ Total } \\
\hline & & & \multirow{2}{*}{$\frac{\text { Política }}{4}$} & Negócios & onvençõe & Eventos & \multirow{2}{*}{$\frac{\text { Lazer }}{10}$} & \multirow{2}{*}{$\frac{\text { Outros }}{20}$} & \multirow{2}{*}{$\begin{array}{r}\text { Turismo } \\
\text { Cívico }\end{array}$} & \multirow{2}{*}{\begin{tabular}{|c|} 
Turismo \\
le Saúde \\
1
\end{tabular}} & \multicolumn{2}{|c|}{\begin{tabular}{|l|l|} 
Turismo & Turismo \\
Religioso & Místico \\
\end{tabular}} & \\
\hline \multirow{2}{*}{\multicolumn{3}{|c|}{$\begin{array}{ll}\text { Qual sui Funcionár Frequênci } \\
\text { ocupaçế público } & \text { Porcentad }\end{array}$}} & & 24 & 13 & 2 & & & & & 1 & 0 & 72 \\
\hline & & & 5,6 & 33,3 & 18,1 & 2,8 & 13,9 & 27,8 & , 0 & 1,4 & 1,4 & , 0 & 100,0 \\
\hline \multirow[t]{8}{*}{ atual? } & \multirow{2}{*}{$\begin{array}{l}\text { Funcionár } \\
\text { privado }\end{array}$} & Frequênci & 4 & 54 & 5 & 2 & 38 & 20 & 3 & 3 & 1 & 2 & 123 \\
\hline & & Porcentag & 3,3 & 43,9 & 4,1 & 1,6 & 30,9 & 16,3 & 2,4 & 2,4 & ,8 & 1,6 & 100,0 \\
\hline & \multicolumn{2}{|c|}{ Profission: Frequênci } & 4 & 21 & 2 & 6 & 8 & 3 & 0 & 0 & 1 & 0 & 41 \\
\hline & Liberal & Porcentag & 9,8 & 51,2 & 4,9 & 14,6 & 19,5 & 7,3 & 0 &, 0 & 2,4 & 0 & 100,0 \\
\hline & \multirow[t]{2}{*}{ Autônomo } & Frequênci & 2 & 22 & 3 & 3 & 22 & 10 & 0 & 2 & 1 & 1 & 60 \\
\hline & & Porcentag & 3,3 & 36,7 & 5,0 & 5,0 & 36,7 & 16,7 & 0 & 3,3 & 1,7 & 1,7 & 100,0 \\
\hline & \multirow[t]{2}{*}{ Outros } & Frequênci & 1 & 0 & 3 & 1 & 3 & 5 & 0 & 2 & 0 & 0 & 13 \\
\hline & & Porcentad & 7,7 &, 0 & 23,1 & 7,7 & 23,1 & 38,5 & , 0 & 15,4 & , 0 & ,0 & 100,0 \\
\hline \multirow[t]{2}{*}{ Total } & \multicolumn{2}{|c|}{ Frequência } & 8 & 118 & 24 & 13 & 80 & 58 & 3 & 8 & 4 & 3 & 300 \\
\hline & \multicolumn{2}{|c|}{ Porcentagem } & 2,7 & 39,3 & 8,0 & 4,3 & 26,7 & 19,3 & 1,0 & 2,7 & 1,3 & 1,0 & 100,0 \\
\hline
\end{tabular}

Analisando os cruzamentos acima, aparentemente notou-se que independentemente da ocupação a maioria dos entrevistados relaciona Brasília à política, seguido de negócios. Entretanto, aparentemente percebeu-se que o principal motivo da viagem independentemente da função foi "negócios", exceto para os autônomos que vieram na mesma proporção para lazer.

- Renda x Comparação com outras cidades

\begin{tabular}{|c|c|c|c|c|c|c|}
\hline & & & \multicolumn{3}{|c|}{$\begin{array}{l}\text { Comprando Brasília com outras capitais } \\
\text { visitadas pelo senhor (a), levando em conta } \\
\text { os produtos/serviços oferecidos por } \\
\text { empresas públicas e privadas da cidade, o } \\
\text { preço pago condiz com o padrão oferecido? }\end{array}$} & \multirow[b]{2}{*}{ Total } \\
\hline & & & Sim & Às vezes & Não & \\
\hline \multirow{12}{*}{$\begin{array}{l}\text { Nível } \\
\text { de } \\
\text { Renda }\end{array}$} & $\mathrm{R} \$ 700$ & Frequência & 8 & 16 & 30 & 54 \\
\hline & & Porcentagem & $14,8 \%$ & $29,6 \%$ & $55,6 \%$ & $100,0 \%$ \\
\hline & $\mathrm{R} \$ 701$ a $\mathrm{R} \$ 1.400$ & Frequência & 20 & 16 & 17 & 53 \\
\hline & & Porcentagem & $37,7 \%$ & $30,2 \%$ & $32,1 \%$ & $100,0 \%$ \\
\hline & $\mathrm{R} \$ 1.401$ a $\mathrm{R} \$ 2.400$ & Frequência & 13 & 16 & 11 & 40 \\
\hline & & Porcentagem & $32,5 \%$ & $40,0 \%$ & $27,5 \%$ & $100,0 \%$ \\
\hline & $\mathrm{R} \$ 2.401$ a $\mathrm{R} \$ 3.500$ & Frequência & 5 & 15 & 11 & 31 \\
\hline & & Porcentagem & $16,1 \%$ & $48,4 \%$ & $35,5 \%$ & $100,0 \%$ \\
\hline & $\mathrm{R} \$ 3.501$ a $\mathrm{R} \$ 4.500$ & Frequência & 12 & 14 & 12 & 38 \\
\hline & & Porcentagem & $31,6 \%$ & $36,8 \%$ & $31,6 \%$ & $100,0 \%$ \\
\hline & Acima de $R \$ 4.501$ & Frequência & 31 & 42 & 19 & 92 \\
\hline & & Porcentagem & $33,7 \%$ & $45,7 \%$ & $20,7 \%$ & $100,0 \%$ \\
\hline \multirow[t]{2}{*}{ Total } & & Frequência & 89 & 119 & 100 & 308 \\
\hline & & Porcentagem & $28,9 \%$ & $38,6 \%$ & $32,5 \%$ & $100,0 \%$ \\
\hline
\end{tabular}


Examinando o cruzamento acima, aparentemente observou-se que quanto menor a renda, menor é o grau de concordância entre o preço cobrado pelos produtos/serviços oferecidos na cidade. Pois, como mostra os dados coletados, apenas as pessoas com renda inferior/igual a $R \$ 700$ e as pessoas com renda entre $R \$ 2.401$ a $R \$ 3.500$ não estão satisfeitos, havendo um empate entra a opinião dos entrevistados com renda entre $R \$ 3.501$ a $R \$ 4.500$.

- Renda x O que o traria novamente à cidade

\begin{tabular}{|c|c|c|c|c|c|c|c|c|c|c|c|c|c|}
\hline & \multicolumn{10}{|c|}{ O que o traria novamente à cidade? } & \multirow[b]{2}{*}{ Total } \\
\hline & & & Política & Negócios & Donvenções & Eventos & Lazer & $\begin{array}{l}\text { Turismo } \\
\text { Cívico }\end{array}$ & $\begin{array}{l}\text { Turismo } \\
\text { de Saúde }\end{array}$ & \begin{tabular}{|l|} 
Turismo \\
Religioso
\end{tabular} & $\begin{array}{l}\text { Turismo } \\
\text { Místico }\end{array}$ & Outros & \\
\hline \multirow{12}{*}{$\begin{array}{l}\text { Nível } \\
\text { de } \\
\text { Rende }\end{array}$} & $\mathrm{R} \$ 700$ & Frequência & 2 & 15 & 5 & 9 & 24 & 4 & 4 & 1 & 0 & 9 & 54 \\
\hline & & Porcentag & 3,7 & 27,8 & 9,3 & 16,7 & 44,4 & 7,4 & 7,4 & 1,9 & 0 & 16,7 & 100,0 \\
\hline & $\mathrm{R} \$ 701$ a $\mathrm{F}$ & Frequência & 0 & 19 & 2 & 9 & 22 & 1 & 0 & 1 & 1 & 7 & 53 \\
\hline & 1.400 & Porcentag & ,0 & 35,8 & 3,8 & 17,0 & 41,5 & 1,9 & 0 & 1,9 & 1,9 & 13,2 & 100,0 \\
\hline & $\mathrm{R} \$ 1.401 \mathrm{a}$ & Frequência & 0 & 13 & 4 & 7 & 18 & 2 & 1 & 2 & 0 & 3 & 40 \\
\hline & $\mathrm{R} \$ 2.400$ & Porcentag & 0 & 32,5 & 10,0 & 17,5 & 45,0 & 5,0 & 2,5 & 5,0 & 0 & 7,5 & 100,0 \\
\hline & $\mathrm{R} \$ 2.401 \mathrm{a}$ & Frequência & 3 & 11 & 5 & 6 & 11 & 3 & 0 & 0 & 0 & 5 & 31 \\
\hline & $\mathrm{R} \$ 3.500$ & Porcentag & 9,7 & 35,5 & 16,1 & 19,4 & 35,5 & 9,7 & 0 & 0 & 0 & 16,1 & 100,0 \\
\hline & $\mathrm{R} \$ 3.501 \mathrm{a}$ & Frequência & 5 & 20 & 5 & 5 & 12 & 5 & 0 & 0 & 0 & 5 & 37 \\
\hline & $\mathrm{R} \$ 4.500$ & Porcentag & 13,5 & 54,1 & 13,5 & 13,5 & 32,4 & 13,5 & 0 & 0 & 0 & 13,5 & 100,0 \\
\hline & Acima de $F$ & Frequência & 15 & 65 & 24 & 31 & 22 & 7 & 1 & 2 & 0 & 11 & 92 \\
\hline & 4.501 & Porcentag & 16,3 & 70,7 & 26,1 & 33,7 & 23,9 & 7,6 & 1,1 & 2,2 & 0 & 12,0 & 100,0 \\
\hline \multirow[t]{2}{*}{ Total } & Frequência & & 25 & 143 & 45 & 67 & 109 & 22 & 6 & 6 & 1 & 40 & 307 \\
\hline & Porcentage & & 8,1 & 46,6 & 14,7 & 21,8 & 35,5 & 7,2 & 2,0 & 2,0 & 3 & 13,0 & 100,0 \\
\hline
\end{tabular}

Aparentemente, ao verificar o que traria os turistas novamente a Brasília, percebeu-se que pessoas com renda entre $R \$ 3.501$ a $R \$ 4.500$ e com renda acima de $R \$ 4.501$ voltariam à cidade por negócios. Entretanto, as pessoas com renda inferior às citadas voltariam por lazer, exceto os entrevistados com renda entre $\mathrm{R} \$ 2.401$ a $\mathrm{R} \$ 3.500$ que se dividem entre as duas opções. 
- Educação x O (a) senhor (a) voltaria a Brasília

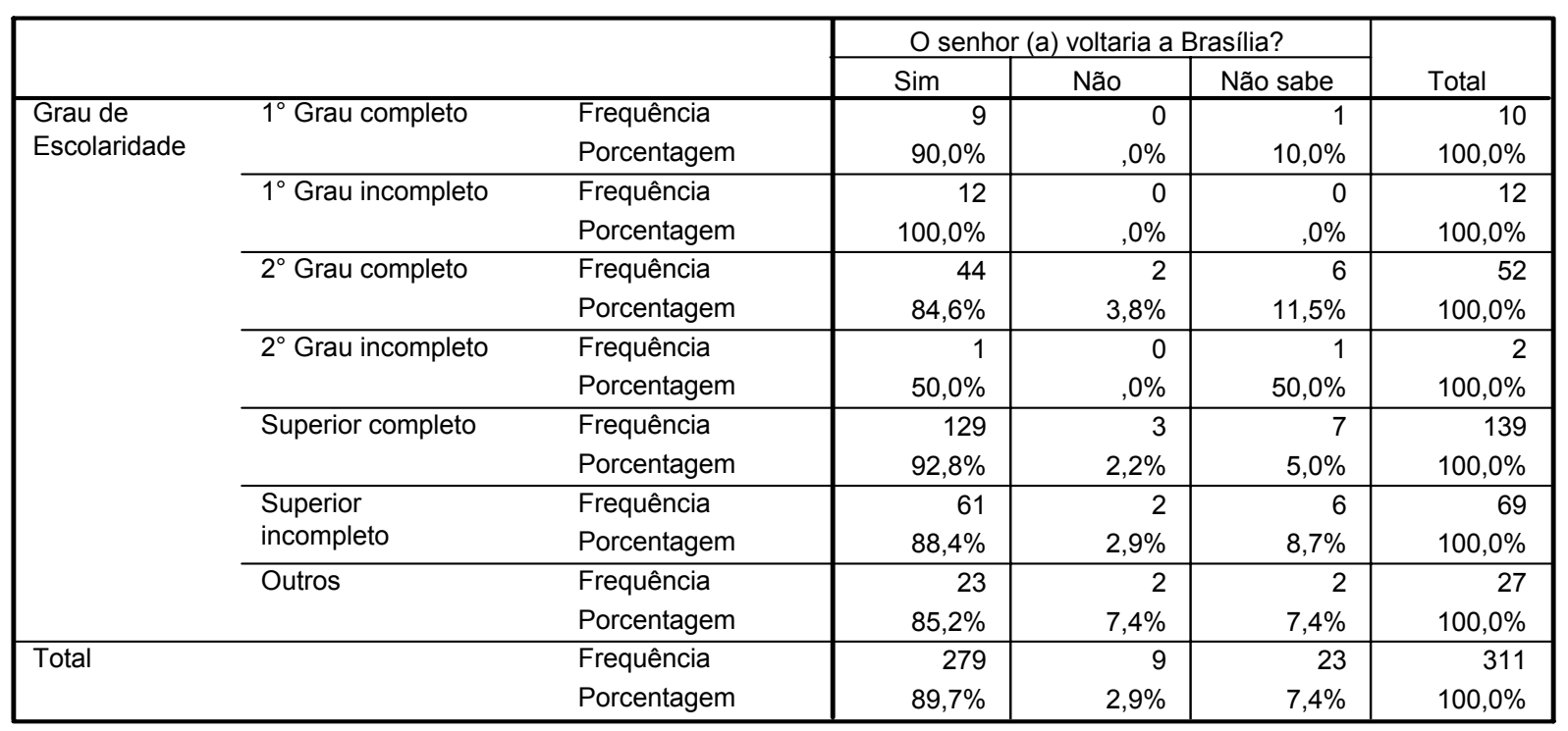

Nesse cruzamento, aparentemente conclui-se que dentre os entrevistados independentemente do grau de escolaridade a grande maioria voltaria à cidade. Sendo o número mais representativo os entrevistados com nível superior completo $92,8 \%$, superior incompleto $88,4 \%$ e outros - pós-graduados e doutores, $85,2 \%$. 
- Educação x Percepção de turismo em Brasília

\begin{tabular}{|c|c|c|c|c|c|c|c|c|c|c|c|c|}
\hline & \multicolumn{10}{|c|}{ Quando pensa em turismo em Brasília, o senhor (a) relaciona a que? } & \multirow[b]{2}{*}{ Total } \\
\hline & & Política & legócios & onvençõe & Eventos & \multirow[t]{2}{*}{ Lazer } & \multicolumn{4}{|c|}{ Turismo Turismo Turismo Turismo } & Outros & \\
\hline Grau de & $1^{\circ}$ Grau comp Frequênc & 0 & 4 & 0 & 3 & & 0 & 1 & 0 & 0 & 0 & 10 \\
\hline Escolarid & Porcentad & 0 & 40,0 & 0 & 30,0 & 20,0 & 0 & 10,0 & 0 & ,0 & 0 & 100,0 \\
\hline & $1^{\circ} \mathrm{Grau}$ incon Frequênc & 2 & 2 & 0 & 1 & 3 & 1 & 2 & 1 & 0 & 0 & 12 \\
\hline & Porcentad & 16,7 & 16,7 &, 0 & 8,3 & 25,0 & 8,3 & 16,7 & 8,3 &, 0 & , 0 & 100,0 \\
\hline & $2^{\circ}$ Grau comp Frequênc & 16 & 4 & 4 & 8 & 16 & 10 & 2 & 0 & 0 & 2 & 54 \\
\hline & Porcentas & 29,6 & 7,4 & 7,4 & 14,8 & 29,6 & 18,5 & 3,7 &, 0 &, 0 & 3,7 & 100,0 \\
\hline & $2^{\circ} \mathrm{Grau}$ incon Frequênc & 1 & 0 & 0 & 0 & 0 & 1 & 0 & 0 & 0 & 0 & 2 \\
\hline & Porcentad & 50,0 & , 0 &, 0 & , 0 &, 0 & 50,0 &, 0 & ,0 &, 0 &, 0 & 100,0 \\
\hline & Superior comı Frequênc & 63 & 42 & 32 & 39 & 27 & 38 & 2 & 2 & 7 & 7 & 138 \\
\hline & Porcentad & 45,7 & 30,4 & 23,2 & 28,3 & 19,6 & 27,5 & 1,4 & 1,4 & 5,1 & 5,1 & 100,0 \\
\hline & Superior incor Frequênc & 28 & 20 & 7 & 17 & 19 & 16 & 0 & 0 & 2 & 1 & 69 \\
\hline & Porcentad & 40,6 & 29,0 & 10,1 & 24,6 & 27,5 & 23,2 & ,0 & ,0 & 2,9 & 1,4 & 100,0 \\
\hline & Frequênc & 13 & 6 & 7 & 8 & 2 & 5 & 0 & 1 & 3 & 1 & 27 \\
\hline & Porcentad & 48,1 & 22,2 & 25,9 & 29,6 & 7,4 & 18,5 & 0 & 3,7 & 11,1 & 3,7 & 100,0 \\
\hline Total & Frequência & 123 & 78 & 50 & 76 & 69 & 71 & 7 & 4 & 12 & 11 & 312 \\
\hline & Porcentagem & 39,4 & 25,0 & 16,0 & 24,4 & 22,1 & 22,8 & 2,2 & 1,3 & 3,8 & 3,5 & 100,0 \\
\hline
\end{tabular}

Analisando esse cruzamento, aparentemente concluiu-se que a percepção dos visitantes sobre turismo na cidade é atribuída a política com o maior percentual de $39,4 \%$, seguido de negócios com $25 \%$ e eventos com $24,4 \%$.

\subsection{Potenciais segmentos que podem ser alvo de esforços mercadológicos.}

Para o Ministério do Turismo, na cartilha de segmentação do turismo (2006, p. 3):

Os produtos e roteiros turísticos, de modo geral, são definidos com base na oferta (em relação à demanda), de modo a caracterizar segmentos ou tipos de turismo específicos. Assim, as características dos segmentos da oferta é que determinam a imagem do roteiro, ou seja, a sua identidade, e embasam a estruturação do produto, sempre em função da demanda. (...). 
Constatou-se na pesquisa que o turismo de lazer, vem despontando nos últimos dois anos (baseado no estudo de 2005 em anexo) como o segmento em maior potencial para um melhor investimento dos empresários do ramo.

Gráfico 10: Motivo da viagem

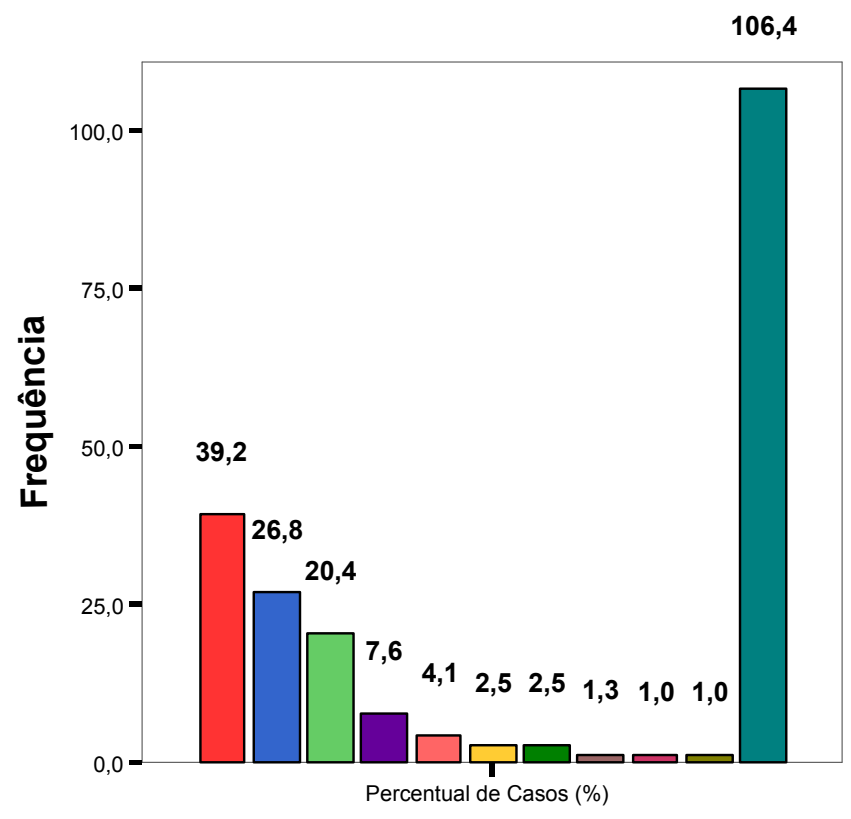

\begin{tabular}{|ll|}
$\square$ Negócios & $\square$ Turismo de Saúde \\
$\square$ Lazer & $\square$ Turismo Religioso \\
$\square$ Outros & $\square$ Turismo Cívico \\
$\square$ Convenções & $\square$ Turismo Místico \\
$\square$ Eventos & $\square$ Total \\
$\square$ Política & \\
\hline
\end{tabular}

\subsection{Principais motivos que trazem as pessoas a Brasília}

Na elaboração do questionário, houve a preocupação em identificar qual o motivo da viagem e um potencial motivo que traria os visitantes novamente à cidade, como mostra as questões 7 e 13 do questionário.

Analisando o percentual do principal motivo da viagem, observou-se que $39,2 \%$ dos entrevistados vieram a Brasília a negócios, contrapondo-se a 26,8\% de lazer e 20,4\% 
de outros, sendo, os outros motivos elencados pouco procurados como mostra o gráfico 10 acima citado.

Relacionando a $13^{\mathrm{a}}$ (O que o traria novamente à cidade?) questão do questionário com a $7^{a}$ (Motivo da viagem?), levando em consideração que os entrevistados marcaram mais de um motivo, observou-se que "negócios" e "lazer" continuam ocupando as primeiras posições, enquanto que "eventos" se destaca como a $3^{a}$ opção. Como enfoca o gráfico 11.

Gráfico 11: Freqüência do motivo que o traria novamente a cidade.

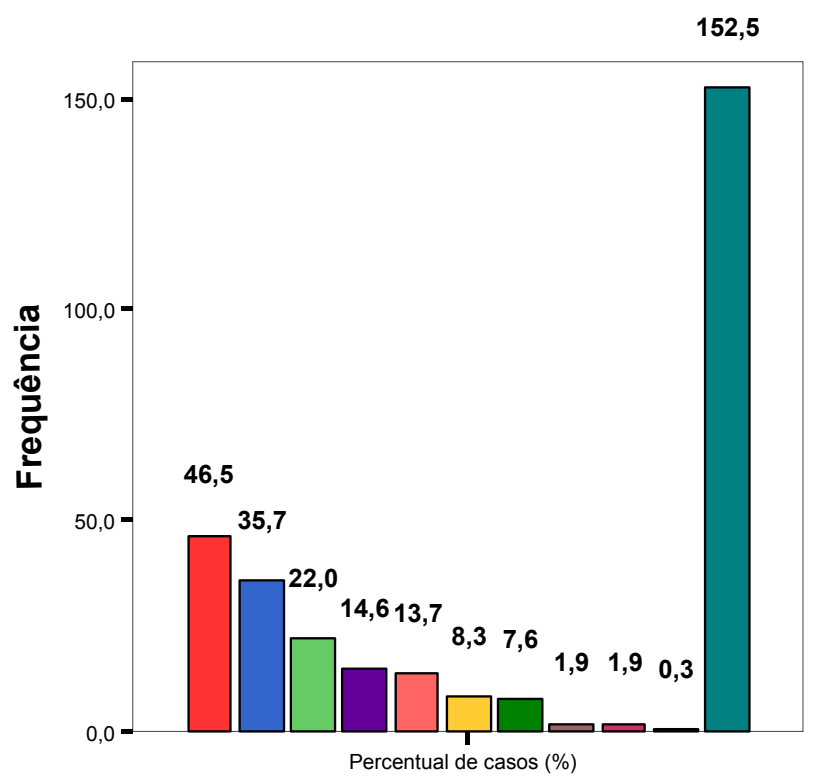

\begin{tabular}{|ll|}
\hline Negócios & $\square$ Turismo Cívico \\
$\square$ Lazer & $\square$ Turismo de Saúde \\
$\square$ Eventos & $\square$ Turismo Religioso \\
$\square$ Convenções & $\square$ Turismo Místico \\
$\square$ Outros & $\square$ Total \\
$\square$ Política & \\
\hline
\end{tabular}

Analisando os gráficos acima citados, concluiu-se que o principal motivo da viagem continua sendo negócios como estabelecido no anexo A (estudo do turismo receptivo no Distrito Federal de 2005).

Verificou-se também que a opção "lazer", que no estudo do turismo receptivo do Distrito Federal de 2005 , ocupava a $4^{\mathrm{a}}$ posição, passou depois dessa pesquisa a ocupar o $2^{\circ}$ motivo da viagem e de uma próxima visita. 
Baseado nos resultados obtidos percebeu-se que Brasília desponta de 2005 aos dias atuais como uma cidade receptiva ao turismo de lazer.

\subsection{Expectativas dos visitantes em relação aos produtos e serviços turísticos que a cidade oferece.}

Para responder esse tópico foi utilizada a análise da freqüência e os cruzamentos da $16^{a}$ (Comparando Brasília com outras capitais visitadas pelo senhor (a), levando em conta os produtos/serviços (hospedagem, gastronomia, lazer, transporte) por empresas públicas e privadas da cidade, o preço pago condiz com o padrão oferecido?) questão do questionário, a qual questiona as diferentes estratégias do posicionamento de Brasília por preço, concorrente e qualidade da oferta.

A freqüência dessa questão estabelece que 104 pessoas que correspondem a 33,12\% da amostra não está satisfeito com o preço cobrado pelos produtos e serviços ofertados como mostra o gráfico 12.

Gráfico 12 - Expectativas dos visitantes em relação aos produtos e serviços turísticos que Brasília oferece.

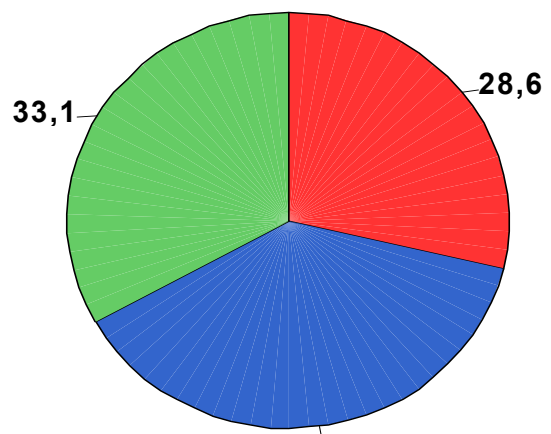

38,2
Comprando Brasília com outras capitais visitadas pelo senhor (a),

levando em conta os produtos/serviços oferecidos por empresas públicas e privadas da cidade, o preço pago condiz com o padrão oferecido? $\square \operatorname{sim}$

Às vezes

Não 
Cruzamento: Grau de escolaridade x Comparando a outras cidades

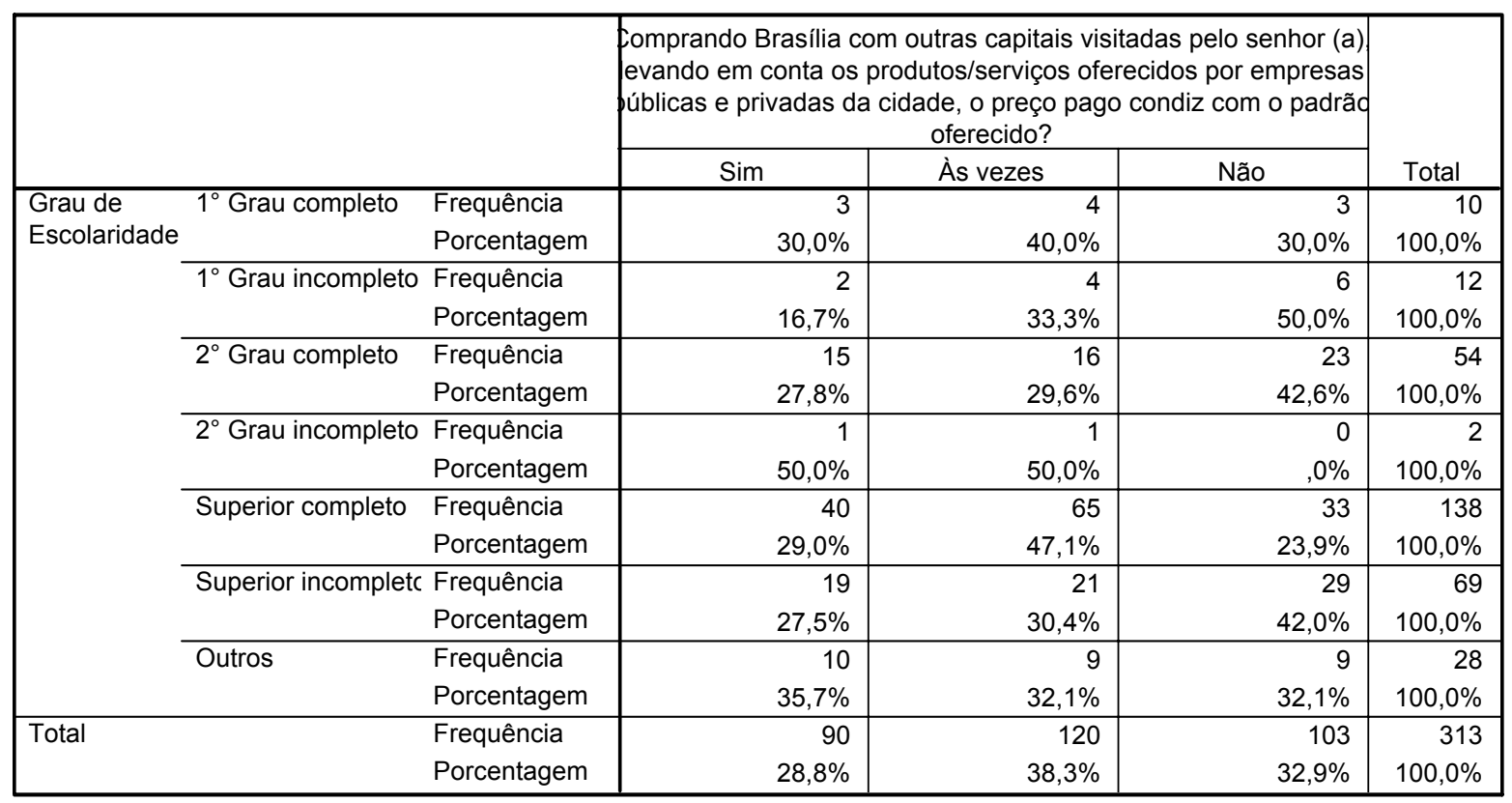

Analisando o cruzamento Grau de escolaridade x Comparando a outras cidades, aparentemente percebeu-se que independentemente do grau de escolaridade dos entrevistados, o resultado obtido em relação ao preço cobrado pelos produtos e serviços não são aceitos.

Cruzamento: Ocupação x Comparando a outras cidades

\begin{tabular}{|c|c|c|c|c|c|c|}
\hline & & & \multicolumn{3}{|c|}{$\begin{array}{c}\text { Comprando Brasília com outras capitais visitadas pelo } \\
\text { senhor (a), levando em conta os produtos/serviços } \\
\text { oferecidos por empresas públicas e privadas da cidade, o } \\
\text { preço pago condiz com o padrão oferecido? }\end{array}$} & \multirow[b]{2}{*}{ Total } \\
\hline & & & Sim & Às vezes & Não & \\
\hline \multirow{10}{*}{$\begin{array}{l}\text { Qual sua } \\
\text { ocupação } \\
\text { atual? }\end{array}$} & \multirow{2}{*}{$\begin{array}{l}\text { Funcionário } \\
\text { público }\end{array}$} & Frequência & 26 & 23 & 24 & 73 \\
\hline & & Porcentagem & 35,6 & 31,5 & 32,9 & 100,0 \\
\hline & \multirow{2}{*}{$\begin{array}{l}\text { Funcionário } \\
\text { privado }\end{array}$} & Frequência & 32 & 49 & 42 & 123 \\
\hline & & Porcentagem & 26,0 & 39,8 & 34,1 & 100,0 \\
\hline & \multirow{2}{*}{$\begin{array}{l}\text { Profissional } \\
\text { Liberal }\end{array}$} & Frequência & 7 & 19 & 15 & 41 \\
\hline & & Porcentagem & 17,1 & 46,3 & 36,6 & 100,0 \\
\hline & \multirow[t]{2}{*}{ Autônomo } & Frequência & 18 & 24 & 18 & 60 \\
\hline & & Porcentagem & 30,0 & 40,0 & 30,0 & 100,0 \\
\hline & \multirow[t]{2}{*}{ Outros } & Frequência & 7 & 3 & 3 & 13 \\
\hline & & Porcentagem & 53,8 & 23,1 & 23,1 & 100,0 \\
\hline \multirow[t]{2}{*}{ Total } & \multirow{2}{*}{\multicolumn{2}{|c|}{$\begin{array}{l}\text { Frequência } \\
\text { Porcentagem }\end{array}$}} & 88 & 114 & 99 & 301 \\
\hline & & & 29,2 & 37,9 & 32,9 & 100,0 \\
\hline
\end{tabular}


Explorando o cruzamento acima, aparentemente notou-se que dentre as ocupações a percepção dos turistas entre preço e produtos/serviços oferecidos, reforça as conclusões obtidas acima. Onde a maioria dos entrevistados não está em total acordo com o preço cobrado.

Assim, concluiu-se que entre os entrevistados, utilizando os cruzamentos mais significativos da pesquisa, a grande maioria não percebe nenhum diferencial oferecido na venda dos produtos/serviços que justifique os preços estabelecidos, subjugados através do parâmetro padrão de qualidade oferecido.

\subsection{A percepção dos visitantes sobre a imagem turística de Brasília}

No questionário aplicado encontram-se as questões 14 (Além de ser Patrimônio Histórico e Cultural da Humanidade, na sua vertente turística, Brasília oferece várias opções de diversão, cultura e entretenimento. Quando pensa em turismo em Brasília, o senhor (a) relaciona a que?) e 15 (À que o senhor (a) relaciona Brasília) que objetivam identificar como Brasília se posiciona na mente dos turistas, seguindo duas vertentes distintas e relevantes para o êxito da pesquisa, sendo: a primeira, perceber como a atividade turística é entendida no destino Brasília e a segunda como a cidade Brasília é vista perante os visitantes. 
Gráfico 13 - Visão de turismo em Brasília.

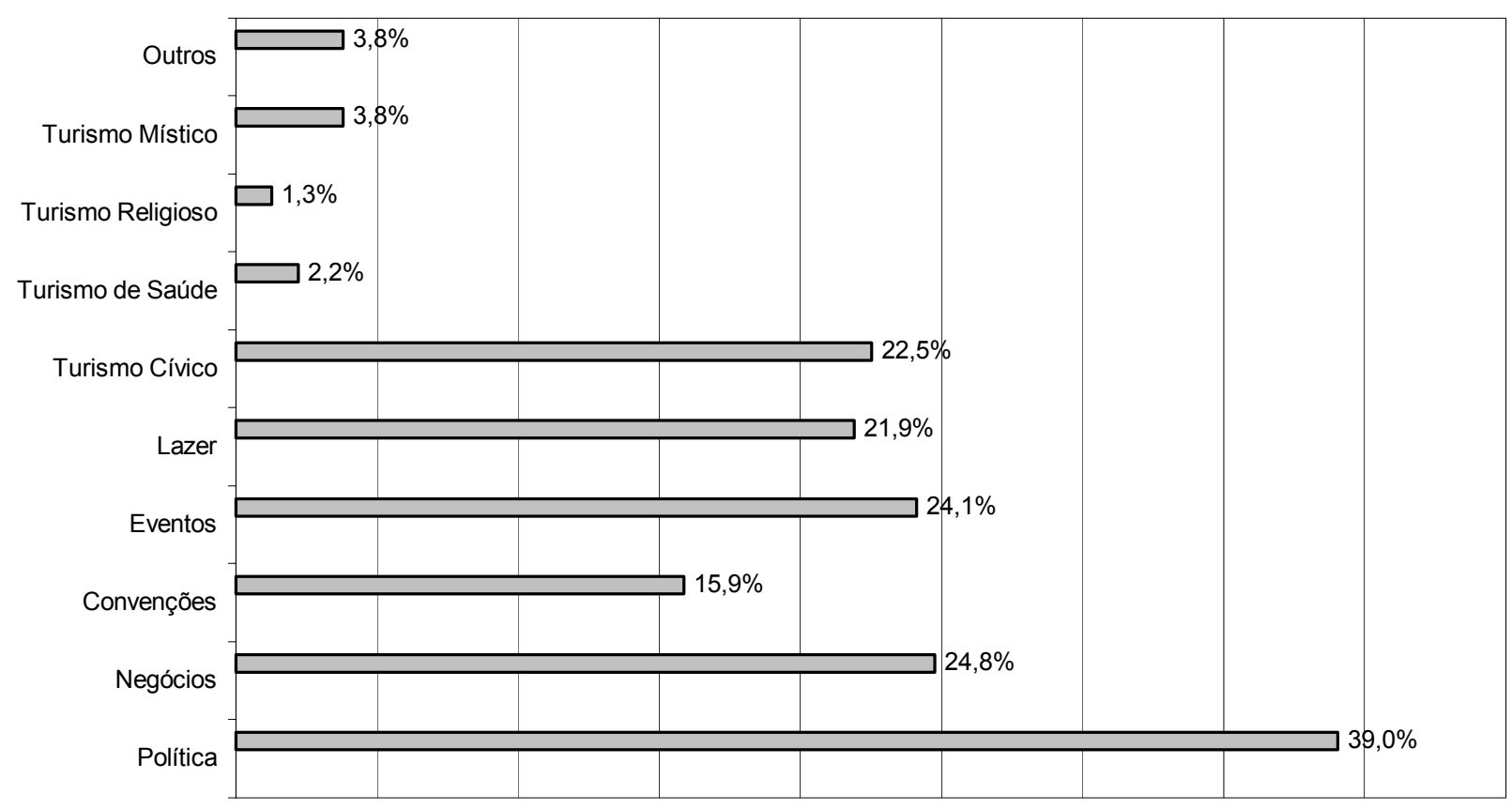

Gráfico 14 - Percepção dos visitantes sobre a Cidade Brasília.

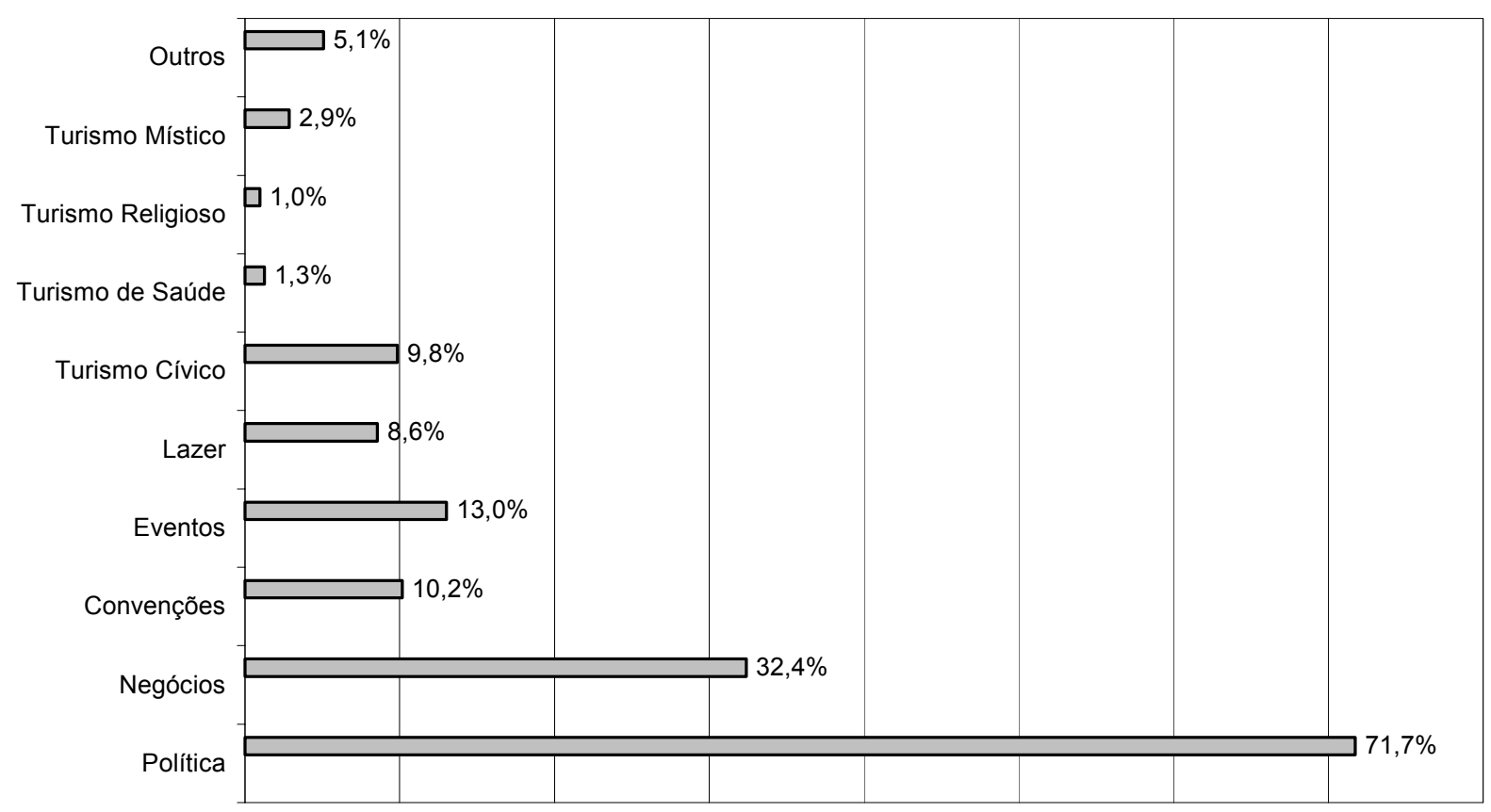


De acordo com os resultados percebeu-se que política, negócios e eventos estão nas duas vertentes entre os primeiros colocados, considerando que em ambas as questões foram marcadas mais de uma opção.

Em ambos os gráficos, fica explícito que as atividades econômicas/políticas permanecem em primeiro plano. O que prova, como afirmado no tópico 4.3 Principais motivos que trazem as pessoas a Brasília, apesar do motivo lazer está se despontando como um segmento promissor, a Cidade ainda não transmite uma imagem que a desvincule das três atividades acima citadas como as principais relacionadas à Brasília. 


\section{CONSIDERAÇÕES FINAIS}

A metodologia utilizada neste estudo foi à pesquisa descritiva quantitativa com uma amostra de 315 visitantes, utilizando como instrumento de coleta de dados o questionário (ver Apêndice A) e o plano de tratamento de dados foi a tabulação no SPSS - Package for Social Sciences.

Através das análises dos dados da pesquisa realizada e respondendo a problemática em questão, conclui-se que os visitantes posicionam Brasília como uma capital política. Entretanto, o principal motivo de emissão de turistas para o destino Brasília é "negócios" o que confirma a força da cidade para esse segmento que, como mostra a pesquisa de turismo receptivo no Anexo A, vem firmando-se desde 2005.

Notou-se também, que a opção "lazer" vem despontando desde a última pesquisa realizada em 2005 como o segundo motivo para atração de visitantes à cidade.

Analisando os dados da pesquisa, observou-se que, dentre os 315 (trezentos e quinze) questionários aplicados, que o perfil dos visitantes corresponde a um maior público do gênero masculino. Sendo a idade predominante independentemente do gênero compreende-se entre 18 a 29 anos. A região Sudeste é a principal emissora de turistas à Brasília, sendo, ainda sobre os entrevistados, a maioria funcionários privados, pessoas que possuem nível superior completo, um nível de renda confortável e solteiros.

Verificou-se que através do perfil dos turistas e suas necessidades, que "negócios" é o principal motivo de viagem à Brasília. Entretanto, percebeu-se que a segmento "turismo de lazer" vem crescendo nos últimos dois anos, pois este ocupa a segunda opção de motivo da viagem da maioria dos visitantes.

Partindo do pressuposto de que grande parte dos entrevistados participa de uma situação financeira confortável e de um nível acadêmico elevado, estima-se que o grau de exigibilidade é alta. Porém, o que demonstra a pesquisa é que além dos fatores 
positivos citados, ficou clara a não concordância com os preços cobrados pelos produtos e serviços, sendo que não há nenhuma justificativa/diferencial encontrada que justifique tais preços.

Em suma, vê-se a necessidade de uma melhoria nos preços cobrados, ou na qualidade dos produtos e serviços (transporte, gastronomia, hospedagem e entretenimento) ofertados na cidade.

Ao analisar como os turistas posicionam Brasília a partir de suas percepções sobre a imagem turística da capital, notou-se que a Cidade está posicionada como um destino político. Apesar do motivo lazer está se despontando como um segmento promissor. Brasília ainda não transmite uma imagem que a desvincule das atividades econômicas/políticas.

Assim, baseado nos resultados alcançados, percebe-se que falta uma política de divulgação e conhecimento dos atrativos e segmentos que Brasília possui. Sendo assim, vê-se necessário a elaboração de um plano de marketing para alavancar esse conhecimento para os turistas e enfim, sanar essa deficiência encontrada nos dados.

A melhoria/criação de uma imagem turística em Brasília seria de grande valia, pois, atribuiria à cidade um valor que a mesma ainda não transmite para a maioria dos visitantes. Levando em consideração que a cidade possui grande receptividade perante aos turistas, já que a possibilidade de retorno é quase que unânime entre os entrevistados.

Enfim, o objetivo proposto foi alcançado, pois, foi respondido o nível de percepção dos visitantes sobre a imagem turística de Brasília, além de identificar novos e promissores segmentos.

\section{REFERÊNCIAS}


ANSARAH, Marilia Gomes. Turismo: segmentação de mercado. São Paulo: Futura, 1999.

ANSARAH, Marilia Gomes. Turismo e segmentação de mercado: Novos seguimentos. In: TRIGO, Luiz Gonzaga Godoi (org.). Analises Regionais e Globais do Turismo Brasileiro, São Paulo: ROCA, 2005.

BENI, Mário Carlos. Análise Estrutural do Turismo. São Paulo: SENAC, 2001.

COSTA, Antônio Fernando Gomes. Guia para elaboração de monografias relatórios de pesquisa: trabalhos acadêmicos, trabalhos de iniciação científica, dissertações, teses e editoração de livros. Rio de Janeiro: Interciência, 2003.

DENCKER, Ada se Freitas Maneti. Métodos e técnicas de Pesquisa em Turismo. São Paulo: Futura, 2001.

GOELDNER, Charles R. et al. Turismo: princípios, práticas e filosofias. Porto Alegre: Bookman, 2002.

HOOLEY, Graham J. et al. Estratégia de Marketing e posicionamento competitivo. São Paulo: Prentice Hall, 2001.

IGNARRA, Luiz Renato. Fundamentos do turismo. São Paulo: Pioneira, 1999.

KOTLER, Philip. Administração de Marketing. São Paulo: Prentice Hall: 2000.

MARCONI, Marina de Andrade. et al. Técnicas de pesquisa. São Paulo: Atlas, 1988.

MIDDLETON, Victor T. C. Marketing de turismo: teoria e prática. Rio de Janeiro: Campus, 2002.

OLIVEIRA, Claudionor dos Santos. Metodologia científica, planejamento e técnicas de pesquisa: uma visão holística do conhecimento humano. São Paulo: LTr, 2000. 
RICHERS, Raimar. Segmentação de mercado: uma visão de conjunto. In: LIMA, Maria Cecília Pimenta; RICHERS, Raimar (org.). Segmentação: opções estratégicas para o mercado brasileiro.. São Paulo: Nobel, 1991.

ROSE, Alexandre Turatti. Turismo: planejamento e marketing. São Paulo: Manole, 2002.

TIGREIRO, Carlos Meira. Marketing e turismo. Rio de Janeiro: QUALITYMARK, 2001.

TURISMO, Ministério do. Segmentação do Turismo: Marcos Conceituais: Introdução. Rio de Janeiro: 2006.

VAZ, Gil Nuno. Marketing turístico: receptivo e emissivo: um roteiro estratégico para projetos mercadológicos públicos e privados. São Paulo: Pioneira, 2001.

ZARDO, Eduardo Flávio. Marketing aplicado ao turismo. São Paulo: Roca, 2003. 
APÊNDICE 


\section{APÊNDICE A}

Questionário aplicado aos turistas em Brasília.

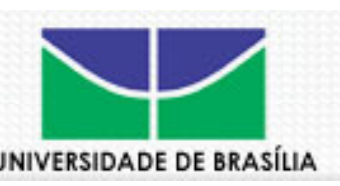

Venho através deste, pedir a colaboração do senhor (a) para a conclusão do trabalho monográfico "A Imagem de Brasília na Visão do Visitante: Um Estudo Sobre Posicionamento Numa Ótica de Marketing", tendo como objetivo geral Identificar o nível de percepção dos visitantes sobre a imagem turística de Brasília, considerando a abordagem mercadológica do "posicionamento" de produtos turísticos.

Desde já agradeço a colaboração,

Thadeu Costa Andrade

\section{QUESTIONÁRIO}

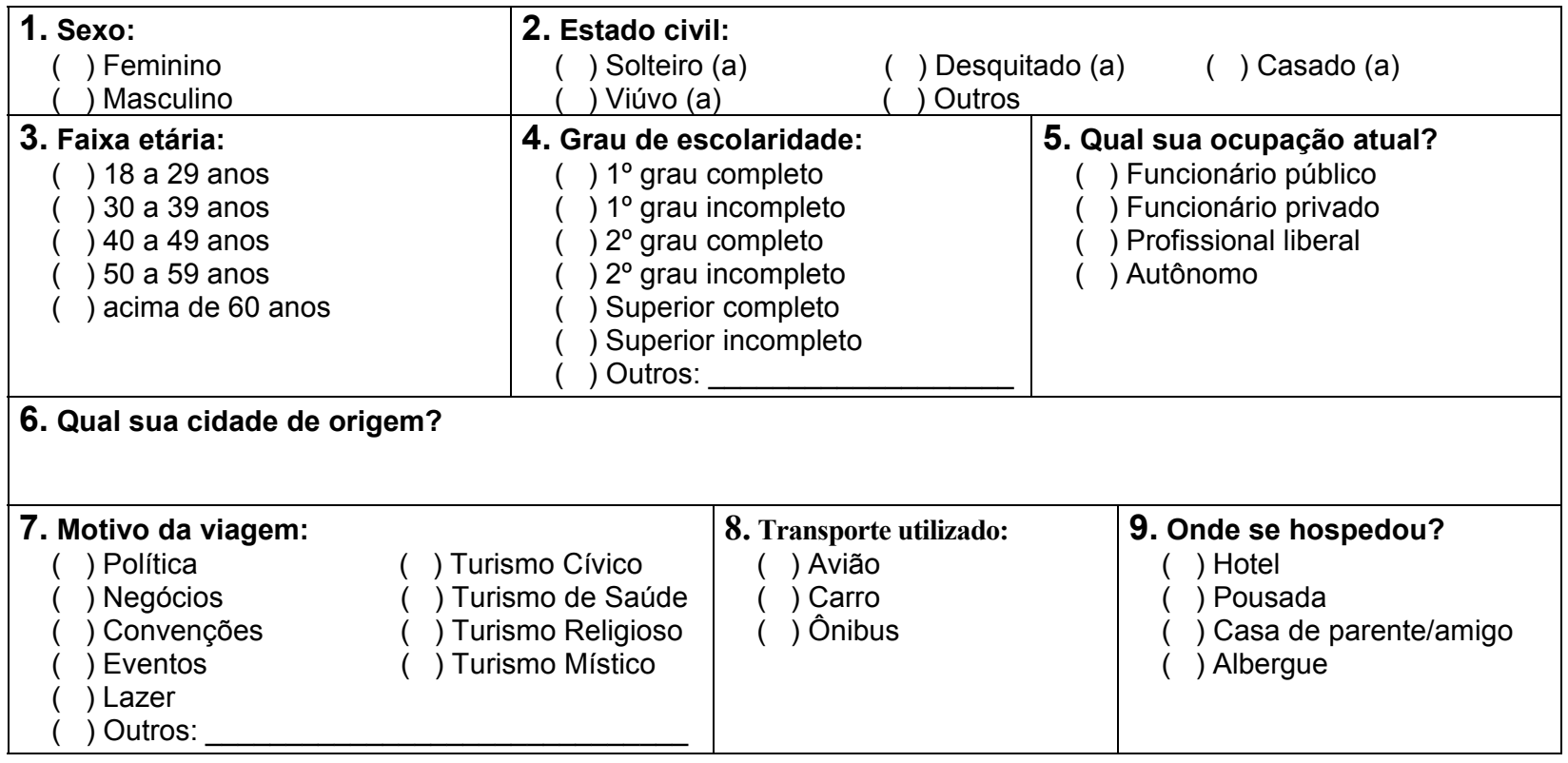




\begin{tabular}{|c|c|c|c|}
\hline $\begin{array}{l}\text { 10. Quantas vezes o senhor (a) } \\
\text { esteve na cidade? } \\
\begin{array}{ll}\text { ( ) } 1 & \text { ( ) } 2 \\
\text { ( ) } 3 & \text { ( ) } 4 \\
\text { ( ) Mais de } 4 & \end{array}\end{array}$ & $\begin{array}{l}\text { 11. Quantos dias o senhor (a) } \\
\text { permaneceu na cidade? }\end{array}$ & \multicolumn{2}{|c|}{$\begin{array}{l}\text { 12. O senhor (a) voltaria a Brasília? } \\
\text { ( ) Sim } \\
\text { ( ) Não } \\
\text { ( ) Não sabe }\end{array}$} \\
\hline $\begin{array}{l}\text { 13. O que o traria novamente } \\
\text { à cidade? } \\
\text { ( ) Política } \\
\text { ( ) Negócios } \\
\text { ( ) Convenções } \\
\text { ( ) Eventos } \\
\text { ( ) Lazer } \\
\text { ( ) Turismo Cívico } \\
\text { ( ) Turismo de Saúde } \\
\text { ( ) Turismo Religioso } \\
\text { ( ) Turismo Místico } \\
\text { ( ) Outros: }\end{array}$ & \multicolumn{2}{|c|}{$\begin{array}{l}\text { 14. Além de ser Patrimônio Histórico e Cultural } \\
\text { da Humanidade, na sua vertente turística, Brasília } \\
\text { oferece várias opções de diversão, cultura e } \\
\text { entretenimento. Quando pensa em turismo em } \\
\text { Brasília, o senhor (a) relaciona a que? } \\
\text { ( ) Política } \\
\text { ( ) Negócios } \\
\text { ( ) Convenções } \\
\text { ( ) Eventos } \\
\text { ( ) Lazer } \\
\text { ( ) Turismo Cívico } \\
\text { ( ) Turismo de Saúde } \\
\text { ( ) Turismo Religioso } \\
\text { ( ) Turismo Místico } \\
\text { ( ) Outros: }\end{array}$} & $\begin{array}{l}\text { o senhor (a) } \\
\text { Brasília? } \\
\text { ica } \\
\text { ócios } \\
\text { venções } \\
\text { tos } \\
\text { smo Cívico } \\
\text { smo de Saúde } \\
\text { mo Religioso }\end{array}$ \\
\hline \multicolumn{3}{|c|}{$\begin{array}{l}\text { 16. Comparando Brasília com outras capitais visitadas pelo senhor (a), } \\
\text { levando em conta os produtos/serviços oferecidos (hospedagem, } \\
\text { gastronomia, lazer, transporte) por empresas públicas e privadas da cidade, o } \\
\text { preço pago condiz com o padrão oferecido? }\end{array}$} & $\begin{array}{l}\text { 17. Nível de renda: } \\
\text { ( ) } R \$ 700 \\
\text { ( ) } R \$ 701 \text { a } R \$ 1.400 \\
\text { ( ) } R \$ 1.401 \text { a } R \$ 2.400 \\
\text { ( ) } R \$ 2.401 \text { a } R \$ 3.500 \\
\text { ( ) } R \$ 3.501 \text { a } R \$ 4.500 \\
\text { ( ) Acima de } R \$ 4.501\end{array}$ \\
\hline
\end{tabular}


ANEXO 
ANEXO A

Dados sobre turismo receptivo no Distrito Federal.

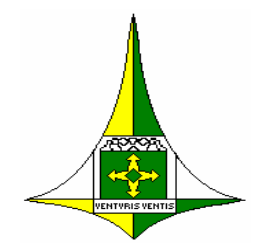

\section{GOVERNO DO DISTRITO FEDERAL}

SECRETARIA DE ESTADO DE TURISMO

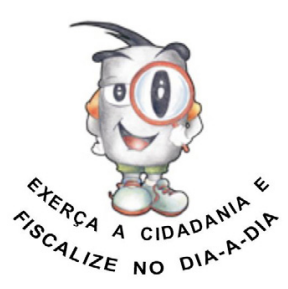

TURISMO RECEPTIVO NO DISTRITO FEDERAL

\begin{tabular}{|l|l}
\hline BRASILEIROS & ESTRANGEIROS \\
\hline
\end{tabular}

\begin{tabular}{|c|c|c|c|}
\hline JAN & 55500 & 3950 & \\
\hline FEV & 62350 & 3500 & \\
\hline MAR & 98200 & 3800 & \\
\hline ABR & 73250 & 1900 & \\
\hline MAI & 77900 & 2100 & \\
\hline JUN & 78500 & 1500 & \\
\hline JUL & 76900 & 2300 & \\
\hline AGO & 100750 & 4100 & \\
\hline SET & 79000 & 2650 & \\
\hline OUT & 69950 & 1800 & \\
\hline NOV & 77600 & 2150 & \\
\hline DEZ & 54750 & 1750 & TOTAL \\
\hline TOTAL & 904650 & 31500 & 936150 \\
\hline
\end{tabular}

\section{TURISTAS DOMÉSTICOS}

Principais Mercados Emissores:

$1^{\circ}$ São Paulo $(22,4 \%)$

$2^{\circ}$ Rio de Janeiro (15\%)

$3^{\circ}$ Goiás $(8 \%)$

$4^{\circ}$ Rio Grande do Sul $(5,6 \%)$ 


\section{GOVERNO DO DISTRITO FEDERAL SECRETARIA DE ESTADO DE TURISMO}

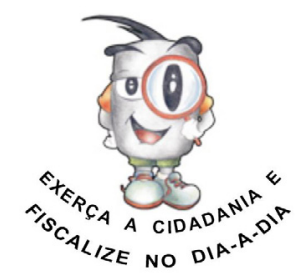

Permanência média: 2,2 noites

Idade Média: 41,4 anos

Motivo da Viagem

$1^{\circ}$ Negócios $(71,4 \%)$

$2^{\circ}$ Outros motivos $(14,1 \%)$

$3^{\circ}$ Convenções $(10,9 \%)$

$4^{\circ}$ Lazer $(3,6 \%)$

Meio de transporte utilizado

$1^{\circ}$ Avião $(89,3 \%)$

$2^{\circ}$ Carro $(9 \%)$

$3^{\circ}$ Ônibus $(1,7 \%)$

\section{Sexo}

$1^{\circ}$ Masculino $(78,7 \%)$

$2^{\circ}$ Feminino $(21,3 \%)$

\section{TURISTAS ESTRANGEIROS}

\section{Emissor para o DF}

$1^{\circ}$ Estados Unidos (20\%)

$2^{\circ}$ França $(8,89 \%)$

$3^{\circ}$ Itália $(8,25 \%)$

$4^{\circ}$ Alemanha $(7,93)$

Permanência Média: 2,2 noites 


\section{GOVERNO DO DISTRITO FEDERAL SECRETARIA DE ESTADO DE TURISMO}

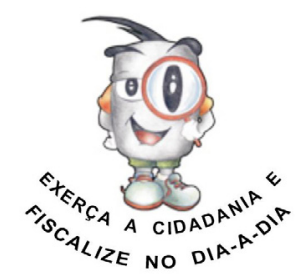

Motivo da Viagem

$1^{\circ}$ Negócios $(45,4 \%)$

$2^{\circ}$ Lazer $(43,3 \%)$

$3^{\circ}$ Convenções $(6,7 \%)$

$4^{\circ}$ Outros motivos $(4,6 \%)$

\section{Meio de transporte}

$1^{\circ}$ Avião $(94,1 \%)$

$2^{\circ}$ Ônibus $(4,8 \%)$

$3^{\circ}$ Carro $(1,1 \%)$

\section{Sexo}

$1^{\circ}$ Masculino $(78,7 \%)$

$2^{\circ}$ Feminino $(21,3 \%)$

\section{MONUMENTOS MAIS VISITADOS}

Templo da Legião da Boa Vontade - LBV (1.055.670);

Torre de TV (323.002)

\section{NÚMERO DE EMPREGOS EXISTENTES NAS ATIVIDADES TURÍSTICAS}

Comércio varejista de outros produtos (9135)

Estabelecimentos hoteleiros (3965)

Outros tipos de alojamento (52)

Restaurantes e estabelecimentos de bebidas, com servico completo (121374)

Transporte rodoviário de passageiros, regular, não urbano (1699)

Transporte rodoviário de passageiros, não regular (480)

Transporte aéreo, regular (794)

Atividades de agências de viagens e organizadores de viagens (2267)

Outras atividades relacionadas ao lazer (2104) 


\section{GOVERNO DO DISTRITO FEDERAL SECRETARIA DE ESTADO DE TURISMO}

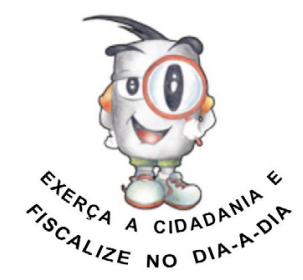

No total, 149.163 pessoas trabalhavam nas atividades turísticas em 2004. Este número não compreende as pessoas que trabalham nos órgãos oficiais de turismo.

\section{PIB DO TURISMO NO DF EM 2004}

$\mathrm{R} \$ 3.046 .479,29$ (envolve apenas gastronomia, hotelaria e transporte). Implicando uma participação de $7,2 \%$ na economia do DF e tornando Brasília o $5^{\circ}$ maior município turístico do Brasil.

Estes números foram retirados com o ano base 2005 com dados da Secretaria de Turismo. Os dados de geração de empregos são medidos pelo Ministério do Trabalho e Emprego - MTE e as classes são as classes da Classificação Nacional de Atividades Econômicas - CNAE estabelecidas pelo IBGE. Os dados do MTE ainda são referentes a 2004.

O PIB do turismo no DF foi calculado pelo Centro de Excelência em Turismo da Universidade de Brasília - CET/UnB com base em dados de 2004. 